\title{
Impact of uncertainties in atmospheric boundary conditions on ocean model solutions
}

\author{
Ayan H. Chaudhuri ${ }^{1 *}$, Rui M. Ponte ${ }^{1}$, Gael Forget ${ }^{2}$
}

1. Atmospheric and Environmental Research (AER), 131 Hartwell Ave, Lexington, MA 02421.

2. Massachusetts Institute of Technology (MIT), 77 Massachusetts Ave, Cambridge, MA 02139 .

$\begin{array}{lll}\text { *Corresponding Author: achaudhu @ aer.com } & \text { (P) } 7817612382 & \text { (F) } 7817612299\end{array}$ 


\section{ABSTRACT}

3 We quantify differences in ocean model simulations derived solely from atmospheric

4 uncertainties and investigate how they relate to overall model errors as inferred from

5 comparisons with data. For this purpose, we use a global configuration of the MITgcm to

6 simulate 4 ocean solutions for 2000-2009 using 4 reanalysis products (JRA-25, MERRA, CFSR

7 and ERA-Interim) as atmospheric forcing. The simulations are compared against observations

8 and against each other for selected variables (temperature, sea-level, sea-ice, streamfunctions,

9 meridional heat and freshwater transports). Forcing-induced differences are comparable in

10 magnitude to model-observation misfits for most near-surface variables in the tropics and sub-

11 tropics, but typically smaller at higher latitudes and polar regions. Forcing-derived differences

12 are expectedly largest near the surface and mostly limited to the upper $1000 \mathrm{~m}$ but can also be

13 seen as deep as 4000m, especially in regions of deep water formation. Errors are not necessarily

14 local in nature and can be advected to different basins. Results indicate that while forcing

15 adjustments might suffice in optimization procedures of near-surface fields and at low-to-mid

16 latitudes, other control parameters are likely needed elsewhere. Forcing-induced differences can

17 be dominated by large spatial scales and specific time scales (e.g. annual), and thus appropriate

18 error covariances in space and time need to be considered in optimization methodologies. 


\section{1. INTRODUCTION}

26 Ocean general circulation models (OGCMs) aid in interpreting observations, assessing dynamics

27 and simulating past and future conditions of the ocean on a variety of space and time scales.

28 Uncertainties in the information derived from OGCMs can arise from deficiencies in the model

29 numerics and physical parameterizations, as well as from inaccurate initial and boundary

30 conditions (e.g., surface forcing fields). Quantifying and understanding these different sources of

31 ocean state uncertainty is important to improve data analysis and climate forecasting capabilities.

33 The availability of globally gridded multi-decadal atmospheric reanalyses (Kistler et al., 2001;

34 Uppala et al., 2005; Onogi et al. 2005; Saha et al., 2010; Rienecker et al., 2011; Dee et al.,

35 2011) has stimulated many studies of the global ocean circulation on climate time scales.

36 Atmospheric fields from these reanalyses are commonly applied as a surface forcing of OGCMs.

37 Uncertainties in these forcing fields (e.g. Chaudhuri et al., 2013) arise from many factors such as

38 differences in model set-up, assimilation schemes, data streams and cloud parameterization

39 schemes amongst others (Milliff et al., 1999; Sun et al., 2003; Drobot et al., 2006; Brunke et al.,

40 2003; Smith et al., 2001; Nicolas and Bromwich, 2011; Wang and McPhaden, 2001; Zhang et

41 al., 1995). Comparisons of surface reanalysis fields against each other and against observations

42 have been conducted on global (Wang et al. 2011; Xue et al. 2012) to regional scales (Bromwich

43 et al. 2010; Jakobson et al. 2012; Naud and Booth, 2014). For example, zonal mean of 4

44 reanalyses for zonal wind stress (Fig. 1) suggest that they are quite similar. However the standard

45 deviations show that there is large variability at higher latitudes, with CFSR wind stress being 
46 the largest. The CFSR wind stress product is in better agreement in terms of mean biases with the

47 QuickSCAT climatology as reported by Xue et al. (2011). The spreads become larger for both

48 mean and standard deviation in the case of precipitation flux (Fig. 1), especially in the equatorial

49 regions. The general conclusion from all the above studies is that no single reanalysis does better

50 than others for all the different variables.

52 Our approach is complementary to studies that have compared and contrasted the responses of

53 different ocean models to a given set of forcing fields. For example, Griffies et al. (2014) forced

5413 ocean models with the same forcing fields and reported that the models responded in a 55 consistent manner. Danabasoglu et al. (2014) however reported significant differences in the 56 Atlantic Meridional Overturning Circulation (AMOC) amongst 18 ocean models forced by

57 Common Reference Ocean Experiment (CORE2) fields from Large and Yeager (2009). They 58 tentatively attributed the large model spread to differences in internal ocean model 59 parameterizations. In such uniform forcing experiments model-model differences can be due to 60 internal model errors whereas model-observation differences can also include atmospheric state 61 errors, experimental design limitations, and/or observational error or limitations (Griffies et al., 62 2014).

64 In this study we attempt to quantify oceanic state uncertainties that derive solely from 65 atmospheric forcing uncertainties and assess their relative importance as compared with overall 66 model-observation errors. This work is in part motivated by the "Estimating the Circulation and 67 Climate of the Ocean" (ECCO) effort (Wunsch et al., 2009; Forget et al., 2015a). ECCO aims at 68 achieving a least squares fit of an OGCM to the great majority of meteorological and oceanic 
69 observations by adjusting a control vector representing initial conditions for temperature and

70 salinity, the surface atmospheric state, and internal model parameters (e.g., Forget et al., 2015a,

71 2015b). In this context, the present study aims at addressing several important questions. How

72 much of model-observation errors can be ascribed to errors in forcing fields? To what extent may

73 forcing field adjustments suffice to reduce model-observation misfits to the expected level of

74 data noise? Are differences in model simulations due to uncertainties in atmospheric forcing

75 fields strongly dependent on location, depth, and time scale?

77 To this end, we employ a global OGCM to simulate the evolving ocean state over 2000-2009

78 under 4 different sets of atmospheric forcing fields. Comparing these simulations against each

79 other and against observations permits an assessment of forcing-induced uncertainties in the

80 context of overall model-observation errors. Details of the methodology are presented in section

81 2. Since the largest impact of atmospheric forcing errors is likely to occur at the surface, we

82 evaluate model-observation differences in variables such as sea surface temperature (SST) and

83 sea-ice cover (SIC) in section 3. We then analyze how errors propagate to the ocean interior by

84 evaluating diagnostics of sea level anomalies (SLA), full depth temperature and oceanic

85 transports in section 4. The spatio-temporal structure of the model errors is discussed in section

86 5. Our findings are summarized in section 6.

2. DATA and METHODS

90 For numerical computations we use the Massachusetts Institute of Technology general

91 circulation model (MITgcm) (Marshall et al. 1997; Adcroft et al., 2004), which is a general 
92 purpose hydrodynamic model that solves the Boussinesq and hydrostatic or non-hydrostatic form

93 of the Navier-Stokes equations for an incompressible fluid. The model uses a grid that reduces

94 grid lines convergence and place grid poles on land. The fully global grid has a zonal spacing of

$951^{\circ}$ longitude. The meridional grid spacing is $0.3^{\circ}$ of latitude within $\pm 10^{\circ}$ of the equator and

96 increases to $1^{\circ}$ latitude outside the Tropics. The model has 50 vertical levels ranging in thickness

97 from $10 \mathrm{~m}$ near the surface to approximately $450 \mathrm{~m}$ at a maximum model depth of $6150 \mathrm{~m}$. The

98 partial-cell formulation of Adcroft et al. (1997), which permits accurate representation of the

99 bathymetry, is used. The model is integrated with real fresh water surface fluxes and properly

100 accounts for their effects on global mean sea-level.

101

102 The ocean model is coupled to a sea-ice model that computes ice thickness, ice concentration, 103 and snow cover as per Zhang et al. (1998) and that simulates a viscous-plastic rheology based on 104 Hibler (1979). The C-grid sea-ice code allows for no-slip and free-slip lateral boundary 105 conditions. Ice mechanics follow a viscous-plastic rheology and the ice momentum equations are 106 solved numerically using line-successive-over-relaxation (LSOR) (Zhang and Hibler, 1997). Ice

107 thermodynamics are represented using a two-layer formulation that conserves enthalpy (Losch et $108 a l ., 2010)$. Ice concentration, volume, snow, ice enthalpy and salinity are advected using the 109 multidimensional 2nd and 3rd-order advection scheme with flux limiters.

111 The ocean model setup uses third order advection with direct space time treatment, and vertical 112 diffusive fluxes are treated implicitly. The model employs a turbulent kinetic-energy based 113 scheme to parameterize vertical mixing (Gaspar et al., 1990). Since eddies are not resolved at 114 coarse horizontal resolution, eddy-induced mixing of properties along isentropes is 
115 parameterized with the GM-Redi scheme. The Redi scheme applies a diffusion operator to mix 116 properties along isentropes (Redi, 1982) and the GM scheme applies an advective flux to

117 parameterize the transport effect of eddies (Gent and McWilliams, 1990). Laplacian diffusion 118 and friction are used except for horizontal friction, which is biharmonic. No-slip bottom, free119 slip lateral, and free surface boundary conditions are employed. Further details about the model 120 configuration are presented in Forget et al. (2015a).

122 We use the MITgcm to simulate 4 ocean solutions for the past decade (2000-2009) using 4 123 reanalysis products: (1) Modern-Era Retrospective Analysis For Research and Applications 124 (MERRA; Rienecker et al., 2011), (2) Japanese Reanalysis (JRA25; Onogi et al. 2005), (3) 125 European Reanalysis (ERA-Interim; Dee et al., 2011) and (4) NCEP Climate Forecast System 126 Reanalysis (CFSR; Saha et al., 2010). Details of the reanalysis products are provided in Table 1. 127 Surface boundary conditions for each simulation set (for each reanalysis product) are prescribed 128 to the model using bulk aerodynamic formulae to calculate surface forcing fluxes. Each set of 129 forcing fields is provided to the model in its native resolution and is then interpolated onto the 130 model grid during runtime. Wind stresses are directly prescribed to the momentum equation. The 131 surface boundary forcing fields (zonal and meridional wind stress, downwelling surface 132 longwave and shortwave radiation, precipitation, air temperature and specific humidity at $2 \mathrm{~m}$ ) 133 from each reanalysis product are prescribed every 6 hours. Each of the reanalysis products is 134 based on its own boundary layer schemes, which bulk formulae can only approximate. Thus 135 forcing errors assessed also include possible uncertainties in boundary layer physics, aside from 136 those in the atmospheric state. A monthly mean climatology of freshwater discharge from land 137 derived from Fekete (2002) is also prescribed for all 4 simulations. Initial conditions for all 
138 simulations are the same and obtained from the ECCO state estimate (Forget et al., 2015a) for

139 December 31, 1997. Each simulation is run for 12 years (1998-2009). The first 2 years are not

140 used and analysis is conducted on model diagnostics over 2000-2009. Internal model

141 parameterizations remain the same while only the atmospheric forcing differs between

142 simulations. The results provide a basis for evaluating model errors solely due to uncertainties in

143 surface forcing.

145 Monthly-mean differences in model solutions for diagnostics of volume, heat and freshwater

146 fluxes, meridional overturning circulation, sea-surface temperature (SST), sea-level anomaly

147 (SLA) are presented to characterize the range of solutions associated with the choice of

148 atmospheric forcing. Errors are partitioned into time-mean and time-variable components;

149 respective uncertainties in surface atmospheric fields can have quite different magnitudes

150 (Chaudhuri et al., 2013). At each grid point, for a given pair of simulations, the time -mean

151 differences $\left(\mathrm{T}_{\mathrm{m}}\right)$ are computed by averaging the 120 monthly difference fields. The time-variable

152 differences $\left(\mathrm{T}_{\mathrm{v}}\right)$ are then computed by subtracting $\mathrm{T}_{\mathrm{m}}$ and linear trends. These values are

153 calculated for each of the 6 pairs that can be formed from the 4 simulations. The root-mean-

154 square (rms) of the set of $T_{m}$ estimates (respectively $T_{v}$ ) divided by $\sqrt{2}$ is denoted as $M_{m}$

155 (respectively $\mathrm{M}_{\mathrm{v}}$ ). The $1 / \sqrt{2}$ factor follows from assuming an equipartition of errors within

156 pairs of simulations. This simplifying assumption is further discussed below. The main goal of

157 this paper is to gauge $\mathrm{M}_{\mathrm{m}}$ and $\mathrm{M}_{\mathrm{v}}$ against estimates of overall model-observation error. The latter

158 (denoted as $D_{m}$ and $D_{v}$ for the time-mean and time-variable components) is estimated by 159 computing the rms of the 4 sets of model-observation misfits associated with the 4 model 160 solutions. The details of the observational datasets used to compute $D_{m}$ and $D_{v}$ are provided in 
161 section 3. $D_{m}$ and $D_{v}$ represent overall model-observation errors that may include model errors 162 due to uncertain initial conditions, parameterized physics, and forcing fields as well as

163 observational and representation errors. Cases of $\mathrm{M}_{\mathrm{m}}<<\mathrm{D}_{\mathrm{m}}$ would thus indicate that forcing field 164 uncertainties are of little relevance to explain model-observation misfits. Conversely $M_{m} / D_{m}$ 165 ratios of order 1 would indicate that reducing forcing field uncertainties is essential to reducing 166 model-observation misfits. Forcing field uncertainties can induce differences in ocean 167 simulations on a variety of time scales including long term model drifts (e.g., see Griffies et al., 168 2009). For the relatively short 10 -yr period of our analysis, the effect of linear trends is 169 accounted for in $\mathrm{M}_{\mathrm{m}}$ and $\mathrm{D}_{\mathrm{m}}$. Conversely linear trends (computed by a least-squares fit) are 170 subtracted before computing $\mathrm{M}_{\mathrm{v}}$ and $\mathrm{D}_{\mathrm{v}}$ in order to focus on interannual and shorter time scales.

172 Treating model runs or retrospective data analyses as realizations of a random process is a 173 commonly accepted method for assessing uncertainties in practice (e.g., see Danabasoglu et al. 174 2014, Balmaseda et al. 2015). This approach is the basis of the present paper as well. The $1 / \sqrt{2}$ 175 factor involved in the definition of $\mathrm{M}_{\mathrm{m}}$ and $\mathrm{M}_{\mathrm{v}}$ is simple to understand. Let $\mathrm{p}$ and $\mathrm{q}$ denote 176 samples taken from a normal distribution with standard deviation $\sigma$ and zero mean. Then the rms 177 of (p-q) will converge to $\sqrt{2}$. Simply scaling the rms of (p-q) by $1 / \sqrt{2}$ in our case is an ad hoc 178 method though. Indeed the sample size (four atmospheric re-analyses) is rather small and, as a 179 result, one cannot affirm that the distribution is normal or otherwise. The estimation of $D_{m}$ and $180 \mathrm{D}_{\mathrm{v}}$ is prone to similar issues. Due to the limited sample size the estimates presented here, while 181 readily insightful, should therefore be taken with caution for the time-mean as well as the time182 variable component. Furthermore errors that are common to all 4 reanalyses may not be clearly 183 distinguished with our methodology. 
184 A brief survey of global model-observation differences in SST and SLA between individual 185 models (Table 2) suggests that their values are quite similar to each other thus further justifying 186 our methodology of equipartition of the error. Furthermore, no one model seems to do better than 187 other models.

\section{ANALYSES of SURFACE VARIABLES}

191 Uncertainties in surface atmospheric forcing are expected to affect strongly the upper ocean

192 fields, which can be directly driven by the boundary fluxes of momentum, heat and freshwater.

193 In this section we present diagnostics for selected surface variables (temperature and sea-ice), 194 including comparisons of $M_{m}$ and $M_{v}$ values with $D_{m}$ and $D_{v}$ values where possible.

\subsection{Sea Surface Temperature (SST)}

197 The role of SST is essential for determining coupling and heat exchange between the atmosphere 198 and ocean. Examining first possible bias errors in SST, values of $\mathrm{M}_{\mathrm{m}}$ are largest $\left(>1{ }^{\circ} \mathrm{C}\right)$ in the

199 Gulf Stream and Kuroshio boundary current systems (Fig. 2). Values of $\mathrm{M}_{\mathrm{m}}>0.6^{\circ} \mathrm{C}$ are also 200 seen near the Agulhas Current, the Malvinas-Brazil Current, the East Australian Current and the 201 Leeuwin Current. Values of $\mathrm{M}_{\mathrm{m}}$ are relatively small over part of the eastern Pacific cold tongue, 202 and at high latitudes. In comparison to $\mathrm{M}_{\mathrm{m}}, \mathrm{M}_{\mathrm{v}}$ magnitudes are generally weaker (Fig. 2). The 203 largest $\mathrm{M}_{\mathrm{v}}$ values $\left(>0.4^{\circ} \mathrm{C}\right)$ are again in the Gulf Stream and Kuroshio boundary current regions.

205 To compute corresponding $\mathrm{D}_{\mathrm{m}}$ and $\mathrm{D}_{\mathrm{v}}$ values, we use a SST product developed at the National 206 Climatic Data Center (NCDC) (Reynolds et al., 2007), which is directly comparable to our model 
207 solutions since it covers 2000-2009 and is of $1^{\circ}$ spatial resolution. This dataset is constructed by

208 using optimum interpolation of SST retrievals. Values of $\mathrm{D}_{\mathrm{m}}$ and $\mathrm{D}_{\mathrm{v}}$ are largest $\left(>1^{\circ} \mathrm{C}\right)$ in

209 western boundary current regions. Moreover $D_{m}$ and $D_{v}$ also show large values along the ice

210 edge, especially in the Greenland and Norwegian seas. Other regions such as the Peruvian

211 upwelling region, the tropical Pacific cold tongue and portions of the Southern Ocean show high

$212 \quad \mathrm{D}_{\mathrm{m}}$ and $\mathrm{D}_{\mathrm{v}}$ values.

213

214 The ratios $M_{m} / D_{m}$ and $M_{v} / D_{v}$, also shown in Fig. 2, are not negligible (> 0.5 or larger) over most

215 of the global oceans. Forcing-induced errors in SST are thus likely important in the context of 216 errors induced in the model by non-forcing related factors such as internal model 217 parameterizations and missing physics. In regions with small ratios $M_{m} / D_{m}$ and $M_{v} / D_{v}$ (northern 218 North Atlantic, the Arctic basin, the Antarctic circumpolar regions and the equatorial Pacific), 219 factors other than atmospheric-related uncertainties must be relevant. Under the Arctic ice cover, 220 SST seems very insensitive to surface forcing errors as expected. In the Southern Ocean, factors 221 controlling the sea-ice edge and also the position of the Antarctic Circumpolar Current are 222 expected to be important. The northern North Atlantic is a region of deep winter convection and 223 thus model errors related to poor resolution of the convective processes are likely involved. The 224 processes controlling the extent and intensity of the eastern equatorial Pacific cold tongue are not 225 well understood ( $\mathrm{Li}$ and Xie, 2014).

228 Sea-ice is a key component of the polar ocean physical system. It controls the exchange of heat, 229 water, momentum, and gases at the sea surface. Changes in the albedo of the surface brought on 
230 by changes in the ice cover over very large areas are a major factor in global climate change. The

231 sea-ice cover has a seasonal nature in both hemispheres with maximum sea-ice extent witnessed

232 in March in the Arctic (co-incident with minimum sea-ice extent in the Southern Ocean) and

233 minimum sea-ice extent during September (co-incident with maximum sea-ice extent in the

234 Southern Ocean).

236 Sea-ice fraction provides an estimate of the fraction of grid cells that are covered with sea-ice

237 and range between 0 (no sea-ice) and 1 (totally covered with sea-ice). Values of $\mathrm{M}_{\mathrm{m}}$ for Arctic

238 sea-ice fraction (Fig. 3) are mostly $<0.1$ with larger differences in the marginal ice zones.

239 Estimates of $\mathrm{M}_{\mathrm{v}}$ for sea-ice fraction are larger than $\mathrm{M}_{\mathrm{m}}$ values in most regions of the Arctic

240 especially in the coastal and marginal ice regions. The largest values (> 0.1) are seen around

241 Svalbard.

243 Comparisons with data are done using the Bootstrap Sea Ice Concentrations from Nimbus-7

244 SMMR and DMSP SSM/I-SSMIS (Comiso, 2002) archived by the National Snow and Ice Data

245 Center (NSIDC; we will use NSIDC sea-ice to refer to this dataset). Values of $\mathrm{D}_{\mathrm{m}}$ are largest (>

246 0.3) around Svalbard and along the ice edge in the Greenland and Norwegian seas.

247 Seasonal/coastal ice regions, such as the East Siberian, Beaufort, Laptev, Kara and Barents seas,

248 show largest $D_{v}$ values (> 0.2). Smaller $\mathrm{M}_{m} / \mathrm{D}_{\mathrm{m}}$ ratios $(<0.5)$ occur in the central Arctic, which

249 has perennial sea-ice cover, whereas coastal and marginal ice regions show larger ratios (> 0.5).

250 Similar spatial patterns are also seen in $\mathrm{M}_{\mathrm{v}} / \mathrm{D}_{\mathrm{v}}$ values. Thus regions of marginal ice cover are 
251 more sensitive to forcing differences than perennial ice-cover regions in the central Arctic (Fig. $2523)$.

255 In the Southern Ocean (Fig. 4), values of $M_{m}$ and $M_{v}$ are relatively small $(<0.2)$ and estimates of $256 \mathrm{D}_{\mathrm{m}}$ and $\mathrm{D}_{\mathrm{v}}$ show values $>0.2$ along the continental margin. Ratios of $\mathrm{M}_{\mathrm{m}} / \mathrm{D}_{\mathrm{m}}$ and $\mathrm{M}_{\mathrm{v}} / \mathrm{D}_{\mathrm{v}}$ are low $257(<0.5)$ in the coastal Indian Ocean sector and along $60^{\circ} \mathrm{S}$ in the Pacific Ocean sector of the 258 Southern Ocean. The marginal-ice zones again display high ratios, which indicate that errors 259 related to atmospheric forcing are particularly important in these regions.

261 Sea-ice thickness uncertainties in the Arctic are examined in Fig. 5. For comparison with data, 262 we use sea-ice thickness estimates derived from ten campaigns of the Ice, Cloud, and land 263 Elevation Satellite (ICESat) mission that span the period 2003-2008 (Kwok et al., 2009). These 264 campaigns represent estimates of the fall and winter Arctic sea ice cover. Each fall and winter 265 ICESat campaign covers a 33-day period from roughly mid-October to mid-November (2003266 2007), and from late February to late March (2004-2008) (Kwok et al., 2009). We average these 267 data into spring and fall bins for each year and compare them with the temporally consistent 268 averages of sea-ice thickness from the model. Since we lack Southern Ocean ice thickness data, 269 only Arctic results are presented in Fig. 5. 
271 Values of $\mathrm{M}_{\mathrm{m}}$ for fall sea-ice thickness (Fig. 5) are on the order of $0.7 \mathrm{~m}$ and mostly greater than

$272 \quad M_{v}$ values. The largest $M_{m}$ values in the fall occur in the Canadian Archipelago. Large values of

$273 \mathrm{D}_{\mathrm{m}}(>1.5 \mathrm{~m})$ are seen all along the coast starting from the Chukchi Sea and eastward towards

274 Svalbard. This pattern is likely because the respective coasts usually become ice-free during the

275 fall and model solutions do not resolve thin-ice conditions well. Both $M_{m} / D_{m}$ and $M_{v} / D_{v}$ ratios

276 indicate that sensitivities to atmospheric forcing can amount to a substantial part of the model-

277 observation differences in the central basin but not along the coastal regions.

Apart from the impact on surface fields, atmospheric forcing errors can also propagate into the

282 interior. In this section we quantify implications of uncertainties in surface atmospheric forcing

283 to errors in sea-level, subsurface temperature, and heat, freshwater, and volume transports.

287 For the time-mean sea-level, values of $\mathrm{M}_{\mathrm{m}}$ (Fig. 6) are largest (>0.03m) in the North Atlantic 288 and Pacific subtropical gyres, as well as in the western tropical Pacific and the South Indian 289 Ocean. For model-observation differences $D_{m}$, we use a mean dynamic topography derived from 290 the Mean Sea Surface constructed by Andersen and Knudsen (2009) and the geoid constructed 291 by Pavlis et al. (2012). The values of $D_{m}$ are $>0.04 \mathrm{~m}$ in most regions and largest near boundary 292 current regions. The ratio of $\mathrm{M}_{\mathrm{m}} / \mathrm{D}_{\mathrm{m}}$ display extensive regions with values $>0.5$, indicating that 
293 errors in time mean sea level associated with forcing uncertainties can be substantial, particularly

294 away from regions of strong currents.

295

296 In terms of sea-level anomaly (SLA) where the time mean sea-level is removed from all 297 products, values of $M_{v}$ are $>0.02 \mathrm{~m}$ in the western basins of the northern hemisphere, i.e., the 298 Gulf Stream-North Atlantic and Kuroshio-Oyashio current systems. However the largest $\mathbf{M}_{\mathrm{v}}$ 299 values $(>0.04 \mathrm{~m})$ in the northern hemisphere are found along the coast of the Chukchi, East 300 Siberian, Laptev and Beaufort Seas. To compute $\mathrm{D}_{\mathrm{v}}$ values we use the Archiving, Validation and 301 Interpretation of Satellite Oceanographic (AVISO) SLA dataset that combines sea surface height

302 data from altimetry missions such as TOPEX/Poseidon, Envisat, Jason-1, and OSTM/Jason-2.

303 We note that the $1 / 3^{\circ}$ binned product contains eddy and fine-scale features, which are not directly 304 comparable to $1^{\circ}$ model solutions. To partly overcome this issue, we apply a Gaussian smoother 305 at $100 \mathrm{~km}$ length scale to the AVISO sea-level dataset. Values of $\mathrm{D}_{\mathrm{v}}$ show spatial patterns similar 306 to $M_{v}$, with high values in the Arctic shelves and western ocean basins. The ratio $M_{v} / D_{v}$ is $>0.4$ 307 for most tropical regions. The sub-tropics and high latitudes show regions of interspersed low 308 ratios $(<0.4)$ such as in the Argentine Basin. Thus SLA errors associated with uncertainties in 309 atmospheric forcing can be a substantial part of the total SLA error in most regions.

\section{4.2. Vertically Integrated Streamfunction $\left(\Psi_{\mathrm{b}}\right)$}

313 The $M_{m}$ and $M_{v}$ values for vertically integrated streamfunction $\left(\Psi_{b}\right)$ are used to investigate first 314 order changes in volume transports due to uncertainties in atmospheric forcing (Fig. 7). The 315 largest $\mathrm{M}_{\mathrm{m}}$ values (> $4 \mathrm{~Sv}$ ) are seen in the Southern Ocean, which is likely related to the large 
316 range in the time-mean zonal wind stresses at these latitudes (Chaudhuri et al., 2013). The

317 northern hemisphere western boundary current regions as well as the equatorial Pacific show $\mathrm{M}_{\mathrm{m}}$

318 values on the order of $2 \mathrm{~Sv}$, which likely relate to uncertainties in wind-stress given its relevance

319 in determining $\Psi_{\mathrm{b}}$. Values of $\mathrm{M}_{\mathrm{v}}$ for $\Psi_{\mathrm{b}}$ are comparable to $\mathrm{M}_{\mathrm{m}}$ values and are also largest (> 2

$320 \mathrm{~Sv}$ ) in the Southern Ocean and in the tropical Pacific. Since there are no observations of $\Psi_{\mathrm{b}}$, we

321 compared the $M_{v}$ values to the signal (i.e. estimates of variability in $\Psi_{b}$ from the 4 simulations).

322 The resulting ratios (not shown) suggest that estimated uncertainties associated with boundary

323 forcing are approximately $10 \%$ of the signal in most regions.

\subsection{Meridional Overturning Streamfunction $\left(\Psi_{\mathrm{o}}\right)$}

327 Estimates of forcing-related uncertainties in $\Psi_{\circ}$ (including bolus terms) are presented in Fig. 8. In 328 the Pacific-Indian basin large values of $\mathrm{M}_{\mathrm{m}}$ are seen in the near surface tropical overturning cells.

329 The tropical cells, which are particularly intense in the Pacific, consist of subtropical water 330 subducted in eastern areas of the ocean, flowing westward and equatorward in the upper 331 pycnocline layers through both western boundary and interior pathways. The cell is closed by 332 upwelling at the equator, with return flow to the subtropics in the surface Ekman layer 333 (McCreary and Lu 1994; Lu et al. 1998). At deeper levels as seen in $\mathrm{M}_{\mathrm{v}}$ the differences in Fig. 8

334 are likely due to the excitation of the equatorial waveguide by differences in the boundary 335 current variability at annual timescales (Jayne and Marotzke, 2001; Reznik and Zeitlin, 2009) or 336 surface winds. 
338 The northern North Atlantic is a region of large winter convection and thus large values of $\mathbf{M}_{\mathrm{m}}$ in

339 this area may be related to differences either in wind stresses (CFSR winds are much stronger

340 than other products in this region (not shown)) or in heat fluxes (JRA ocean heat loss is much

341 stronger than other products (not shown)) imparted by the reanalyses. The equatorial Atlantic

342 show weaker $\mathrm{M}_{\mathrm{v}}$ compared to the Pacific-Indian basin. For the global meridional overturning

343 streamfunction, other than features discussed above values of $\mathrm{M}_{\mathrm{m}}$ are large (>1.5 Sv) in the so-

344 called 'Deacon cell' in the Southern Ocean (Fig. 8). The 'Deacon Cell' is a wind driven

345 meridional cell in which deep water upwells, is blown north by wind stress in an Ekman layer,

346 and sinks at the Antarctic convergence zone (Toggweiler and Samuels 1993; Tomczak and

347 Godfrey 1994). The large difference is likely due to uncertainties in Southern Ocean winds. Zika

348 et al. (2012) have suggested that the Deacon Cell is compensated by a combined effect of 349 transient eddy fluxes and standing meanders. Estimates of $\mathrm{M}_{\mathrm{v}}$ suggest high variability (>1.5 Sv)

350 in the Southern Ocean similar to $\mathrm{M}_{\mathrm{m}}$ values.

352 4.4. Meridional Fluxes of Heat and Freshwater

353 Zonally integrated meridional heat and freshwater fluxes are depicted in Fig. 9. Mean heat 354 transport shows good agreement amongst the 4 solutions with poleward transfer of heat from the 355 equator on the order of 1.5 PW. Values of $\mathrm{M}_{\mathrm{m}}$ for mean heat transport are generally below 0.1 356 PW (Fig. 9) and are thus on the order of 5\% of the signal. The variability (standard deviation) in 357 heat transport estimates are largest (> $3 \mathrm{PW}$ ) in the equatorial regions and taper out towards the 358 higher latitudes (e.g., see Jayne and Marotzke 2001). Values of $\mathrm{M}_{\mathrm{v}}$ are under $0.25 \mathrm{PW}$ or on the 359 order of $5 \%$ of the signal. 
361 Mean freshwater fluxes show large differences between simulations, with $\mathrm{M}_{\mathrm{m}}$ values greater than

$3621 \mathrm{~Sv}$ in southern tropical and sub-tropical latitudes. These differences are mostly comparable to

363 the signal in the equatorial and sub-tropical regions and thus indicate a large forcing-induced

364 spread. Variability in freshwater fluxes is also the largest in the equatorial regions and $\mathrm{M}_{\mathrm{v}}$ values

365 are approximately $10 \%$ of the individual variability displayed by the solutions (Fig. 9). The JRA

366 forcing yields the largest interannual variability in freshwater transports. Saito et al. (2011)

367 suggest that JRA can both overestimate and underestimate areas of precipitation in the $30^{\circ} \mathrm{N}-$

$36830^{\circ} \mathrm{S}$ sub-tropical domain. On the other hand Wang et al. (2011) report that CFSR has better

369 time-mean precipitation distribution over various regions compared to previous generation

370 reanalyses, leading to an improved representation of freshwater fluxes. Trenberth and Fasullo

371 (2010) suggest that most reanalyses overestimate the hydrological cycle with the exception of

372 MERRA. The larger spread amongst the solutions for freshwater transport in the sub-tropical

373 regions can be attributed to large range in estimates of precipitation and evaporation in these

374 reanalyses (Chaudhuri et al. 2013).

375

376 4.5. Vertical Profiles

377 Values of $M_{m}$ and $M_{v}$ for selected zonal and meridional sections of temperature are estimated to 378 investigate the influence of uncertainties in atmospheric forcing at depth. Results indicate that for 379 temperature, the largest differences are expectedly at the surface but substantial effects can also 380 be felt at depth. For brevity, we show representative meridional temperature sections along $381160^{\circ} \mathrm{W}$ in the Pacific and Arctic (Fig. 9). In this case, the estimates of $\mathrm{M}_{\mathrm{m}}$ and $\mathrm{M}_{\mathrm{v}}$ are computed 382 based on monthly mean climatologies created from 2004-2006 from the simulation. This 383 methodology is implemented to enable comparison with an observational climatology, which is a 
384 blend dataset of OCCA (OCean Comprehensive Atlas; Forget et al., 2010) complemented by

385 World Ocean Atlas (Locarnini et al., 2006) in the marginal seas and the Polar science center 386 Hydrographic Climatology (PHC) in the Arctic.

388 The largest $\mathrm{M}_{\mathrm{m}}$ values (> $0.8{ }^{\circ} \mathrm{C}$ ) in Fig. 10 are seen in sub-tropical latitudes within the top $389300 \mathrm{~m}$. In the Southern Ocean, however, errors on the order of $0.05{ }^{\circ} \mathrm{C}$ can be seen to propagate 390 to levels as deep as $4000 \mathrm{~m}$. Values of $D_{m}$ are mostly larger than $M_{m}$ throughout the water 391 column, and also show large discrepancies near the ocean bottom. Ratio of $\mathrm{M}_{\mathrm{m}} / \mathrm{D}_{\mathrm{m}}$ suggests 392 forcing-related errors dominate the near surface and are not totally negligible at depth. Values of $393 \mathrm{M}_{\mathrm{v}}$ and $\mathrm{D}_{\mathrm{v}}$ are $>0.1^{\circ} \mathrm{C}$ in the upper $300 \mathrm{~m}$ and mostly small in the deeper ocean. However the 394 ratio of $M_{v} / D_{v}$ (Fig. 10) display high values not only at the surface but also in the ocean interior 395 in regions such as the Southern Ocean, and equatorial and sub-tropical Pacific.

397 In contrast with the Pacific, the Arctic shows larger $M_{m}$ and $M_{m} / D_{m}$ values at intermediate depths 398 (below 200m) than at the surface (Fig. 10). This is related to the general hydrography of the 399 region where the upper layer (about $50 \mathrm{~m}$ ) is of lower salinity and lower temperature than the 400 rest and remains relatively stable, because the salinity effect on density is bigger than the 401 temperature effect (Aagaard and Carmack, 1989). The upper layer is also modulated by 402 freshwater fluxes from the Siberian and Canadian rivers, which are the same in all our 403 experiments (Rudels et al., 1996). Water in the intermediate layer (200- $800 \mathrm{~m}$ ), where the 404 largest values of $M_{m}$ and $M_{m} / D_{m}$ are seen, is referred to as Atlantic Water. This water mass 405 originates from inflow of the warmer North Atlantic Current through the northern North Atlantic, 
406 which subsequently cools and sinks to form the intermediate Arctic layer, where it circles

407 the Arctic Basin counter-clockwise (Rudels et al., 1994; Dickson et al., 2000). The Atlantic

408 Water mass is mostly warmer than the surface water, and remains submerged only due to the role

409 of salinity in density.

411 Values of $\mathrm{M}_{\mathrm{m}}$ and $\mathrm{M}_{\mathrm{v}}$ for salinity (Fig. 11) show similar structure to the temperature profiles

412 with largest values at the surface, but also propagating into the ocean interior in the Southern

413 Ocean. Values of $\mathrm{D}_{\mathrm{m}}$ and $\mathrm{D}_{\mathrm{v}}$ are expectedly larger at intermediate depths compared to $\mathrm{M}_{\mathrm{m}}$ and $414 \mathrm{M}_{\mathrm{v}}$ values. Ratios of $\mathrm{M}_{\mathrm{m}} / \mathrm{D}_{\mathrm{m}}$ and $\mathrm{M}_{\mathrm{v}} / \mathrm{D}_{\mathrm{v}}$ show a sub-surface maximum (albeit at different depths)

415 in some regions of the Arctic similar to what was seen in the temperature profiles (Fig. 10).

\section{SPATIO-TEMPORAL CHARACTERISTICS OF MODEL ERRORS}

419 Knowing the spatial and temporal structure of model errors related to atmospheric forcing can be 420 helpful in designing appropriate objective functions and optimization procedures. For example, 421 large-scale spatially correlated errors could indicate similar characteristics in the forcing errors 422 and suggest the need to design appropriate covariance matrices with both diagonal and non423 diagonal weights. Similarly, in the case errors are dominated by specific time scales (e.g. annual 424 cycle), it might be advantageous to optimize such time scales separately. The analysis of $\mathbf{M}_{\mathrm{m}}$ 425 values in previous sections clearly suggests that time mean biases show considerable large scale 426 structures and should be considered as a separate term in objective functions. Here we explore 427 further the nature of the time-variable errors, with examples focusing on SST and SLA fields. 
429 To investigate the structure of the SST errors due to uncertainties in atmospheric forcing, we 430 present an empirical orthogonal function (EOF) analysis on SST differences between the ERA431 and JRA-forced simulations that provide a representative example. The first two modes of SST 432 differences between ERA- and JRA-forced simulations (Fig. 12) together explain 35\% of the 433 variance. Both modes show significant large-scale patterns dominated by features in subtropical 434 and subpolar gyres and associated boundary currents, as well as with zonal circulations in the 435 tropics and high latitudes. In addition, their respective time series indicate the presence of a 436 dominant annual cycle.

438 Similar EOF calculations based on differences in SLA between ERA and JRA-forced 439 simulations (Fig. 13) show similar behavior. The leading mode explains $21 \%$ of the variance and 440 shows dominant patterns primarily at the tropics and high latitudes, modulated by the annual 441 cycle. The second mode, which explains $13 \%$ of the variance, also has a near annual frequency 442 and shows a dichotomy in the Arctic between coastal regions and the open ocean, suggestive of 443 the dynamical regimes discussed recently by Fukumori et al. (2015) in relation to wind stress 444 forcing. Fukumori et al. (2015) suggest that a near-barotropic fluctuation is present in the deep 445 basins of the Arctic, which is driven by winds along the continental margins. The winds set up a 446 divergence between the shallow coastal areas and the deep ocean basins, which is most 447 discernable in ocean bottom pressure anomalies that display opposite signs in the two regions.

449 The SST and SLA examples highlighted in Figs. 12 and 13 suggest that model errors due to 450 atmospheric errors can be correlated spatially on large scales, which may reflect broadly 
451 correlated errors in forcing fields. In this case, one should try to specify both diagonal and

452 nondiagonal terms in the covariance matrix used to weight the atmospheric forcing adjustments

453 in optimizing procedures. Furthermore the strong contributions of specific time scales to

454 atmospheric-related uncertainties suggest that separating the atmospheric forcing control vector

455 into several different terms (e.g., mean, annual cycle and long term trend) would be beneficial,

456 provided appropriate weights can be derived for each term.

457

458 6. SUMMARY AND FINAL REMARKS

459

460 In this work, we quantify differences in oceanic variables of interest derived solely from

461 atmospheric uncertainties and investigate how they compare to total model errors (such as due to

462 internal model parameterizations and initial conditions) and observational noise. We present

463 atmospheric uncertainty effects at both the ocean surface level and at deeper depths. At the

464 surface, uncertainties in atmospheric forcing tend to substantially affect SST and SLA estimates

465 especially in tropical and mid latitude regions. However, at high latitudes non-atmospheric

466 factors become more relevant. Cryospheric surface variables such as sea-ice extent are also

467 affected by atmospheric forcing uncertainties especially in the marginal ice zones; however

468 regions under perennial ice-cover are less sensitive to forcing related issues.

470 While errors due to uncertainties in atmospheric forcing tend to be largest near the surface and

471 limited to the upper $1000 \mathrm{~m}$ in most regions, there are exceptions where forcing related errors can

472 reach depths of up to 4000m (e.g. Southern Ocean). Furthermore, these errors are not necessarily 
473 local in nature and can be advected to different basins, such as in the case of temperature errors

474 in Atlantic Water being advected into the Arctic basin (Fig. 10).

476 Forcing-induced errors show coherent spatial structure, as in the EOFs estimated from

477 differences in SLA and SST (Figs. 12 and 13), likely reflecting similar behavior in the forcing

478 errors. Thus, in optimization procedures such as described in Wunsch et al. (2009) and Forget et

479 al. (2015a), adjustments in atmospheric forcing are best weighted by covariance matrices that

480 include both diagonal and nondiagonal elements to account for respective error correlation

481 structures. In addition, forcing-induced model errors can display strong modulation at the annual

482 cycle (Figs. 12 and 13), pointing to possible advantages in partitioning the atmospheric forcing

483 control vector into several different terms (e.g., mean, annual cycle and long term trend).

485 While our discussion mainly distinguishes errors due to atmospheric forcing against the bulk of 486 non-atmospheric factors, quantifying the other contributions would provide a better framework 487 to understand the various sources of model-observation differences and their significance. As a 488 preliminary exercise, we conducted a 10-year simulation (2000-2009) that is initialized and set489 up exactly as the ERA simulation but with different internal parameters for GM intensity, 490 isopycnal diffusivity and diapycnal diffusivity. The internal model parameter values were 491 obtained from a 20-year optimized solution (Forget et al., 2015a). Preliminary assessment of 492 model diagnostics to the original ERA run suggest that errors due to internal parameterizations 493 are expectedly smaller than forcing-induced errors for surface variables such as SST and SLA. 494 However parameterization based errors take precedence for variables such as sea-ice thickness 495 (Fig. 5), $\Psi_{\circ}$ (Fig. 8) and temperature at depth (Fig. 10). Future investigations could incorporate 
496 model sensitivities to initial conditions, bulk flux algorithms and other model parameterizations.

497 Quantitative comparisons of results from this study with results from CORE2 experiments where

498 atmospheric forcing is held constant but different ocean models are used to test model sensitivity

499 (Griffies et al. 2009; Danabasoglu et al. 2014) would provide an indication of sensitivity to

500 model parameterizations. Lastly results discussed here are derived from short 10-year

501 integrations; longer integrations would be preferred in order to assess sensitivities to forcing

502 errors at longer decadal climate scales.

503

504

\section{ACKNOWLEDMENTS}

506 This study was supported by NSF grant ARC-1022733 and NASA grants NNX11AQ12G and 507 NNX14AP33G. The authors would also like to acknowledge support from the NASA Physical 508 Oceanography program for the ECCO project. Simulations were performed on the NASA 509 Advanced Supercomputing (NAS) division's Pleiades supercomputer at NASA/ARC. 


\section{REFERENCES}

513

514

Aagaard, K., Carmack, E.C., 1989. The role of sea ice and other fresh water in the Arctic circulation. Journal of Geophysical Research, 94(C10), 14485-14498.

Adcroft, A., Hill, C., Marshall, J., 1997. The Representation of Topography by Shaved Cells in a Height Coordinate Model. Mon. Wea. Rev,125(9), 2293-2315.

Adcroft, A., Campin, J.-M., Hill, C., Marshall, J. Implementation of an Atmosphere-Ocean General Circulation Model on the Expanded Spherical Cube. Mon. Wea. Rev., 132, 2845-2863

Andersen, O.B., Knudsen, P., 2009. DNSC08 mean sea surface and mean dynamic topography models. Journal of Geophysical Research: Oceans (1978-2012), 114(C11).

Balmaseda M.A and co-authors, 2015. The Ocean Reanalyses Intercomparison Project (ORAIP), Proceedings of the Institute of Marine Engineering, Science, and Technology, J. Operational Oceanogr., 8, s80-s97.

Bosilovich, M.G., Chen, J., Robertson, F.R., Adler, R.F., 2008. Evaluation of Global Precipitation in Reanalyses. J. Appl. Meteor. Climatol., 47, 2279-2299.

Bromwich, D. H., J. P. Nicolas and A. J. Monaghan, 2011. An Assessment of Precipitation Changes over Antarctica and the Southern Ocean since 1989 in Contemporary Global Reanalyses. Journal of Climate, 24 (16), pp 4189-4209.

Brunke, M. A., Z. Wang, X. Zeng, M. Bosilovich, and C.-L. Shie, 2011. An assessment of the uncertainities in ocean surface turbulent fluxes in 11 reanalysis, satellite-derived, and combined global data sets. J. Climate, 24, 5469-5493.

Berrisford, P., Dee, D. P. K. F., Fielding, K., Fuentes, M., Kallberg, P., Kobayashi, S., Uppala, S., 2009. The ERA-Interim Archive. ERA report series, (1), 1-16.

Chaudhuri A.H., Ponte, R.M., Forget, G., Heimbach, P., 2013. A comparison of atmospheric reanalysis surface products over the ocean and implications for uncertainties in air-sea boundary forcing, J. Climate, 26, 153-170.

Comiso, J. C., 2002. A rapidly declining perennial sea ice cover in the Arctic. Geophysical Research Letters, 29(20), 17-1.

Danabasoglu, G., S.G. Yeager, D. Bailey, E. Behrens, M. Bentsen, D. Bi, A. Biastoch, C. Böning, A. Bozec, V.M. Canuto, C. Cassou, E. Chassignet, A.C. Coward, S. Danilov, N. Diansky, H. Drange, R. Farneti, E. Fernandez, P.G. Fogli, G. Forget, Y. Fujii, S.M. Griffies, A. Gusev, P. Heimbach, A. Howard, T. Jung, M. Kelley, W.G. Large, A. Leboissetier, J. Lu, G. Madec, S.J. Marsland, S. Masina, A. Navarra, A.J.G. Nurser, A. Pirani, D. Salas y Mélia, B.L. Samuels, M. Scheinert, D. Sidorenko, A.-M. Treguier, H. Tsujino, P. Uotila, S. Valcke, A. 
Voldoire, and Q. Wangi, 2014. North Atlantic simulations in Coordinated Ocean-ice Reference Experiments phase II (CORE-II). Part I: Mean states. Ocean Model., 73, 76-107.

Dickson, R. R., Osborn, T.J., Hurrell, J. W., Meincke, J., Blindheim, J., Adlandsvik, B., Vinje, T. Alekseev, G., Maslowski, W., 2000. The Arctic ocean response to the North Atlantic oscillation. Journal of Climate 13, 2671-2696.

Drobot, S.D., J.A. Maslanik, C. Fowler, 2006. A long-range forecast of Arctic summer sea-ice minimum extent. Geophys Res Lett 33, L10501.

Fekete, B. M., Vörösmarty, C. J., Grabs, W., 2002. High-resolution fields of global runoff combining observed river discharge and simulated water balances. Global Biogeochemical Cycles, 16(3), 15-1.

Forget, G. Mapping ocean observations in a dynamical framework: A 2004-06 ocean atlas, Journal of Physical Oceanography, 40, 1201-1221, 2010.

Forget, G, Campin, J.M., Heimbach, P., Hill C., Ponte R.M., Wuncsh, C., 2015a. ECCO version 4: an integrated framework for non-linear inverse modeling and global ocean state estimation. Geosci. Model Dev, 8, 3071-3104.

Forget, G., D. Ferreira, and X. Liang, 2015b. On the observability of turbulent transport rates by Argo: supporting evidence from an inversion experiment. Ocean Science, 11, 839-853.

Fukumori, I., Wang, O., Llovel, W., Fenty, I., Forget, G. 2015. A near-uniform fluctuation of ocean bottom pressure and sea level across the deep ocean basins of the Arctic Ocean and the Nordic Seas. Progress in Oceanography, 134, 152-172.

Gaspar, P., Grégoris, Y., Lefevre, J. M., 1990. A simple eddy kinetic energy model for simulations of the oceanic vertical mixing: Tests at station Papa and Long-Term Upper Ocean Study site. Journal of Geophysical Research: Oceans (1978-2012), 95(C9), 16179-16193.

Gent, P. R., Mcwilliams, J. C., 1990. Isopycnal mixing in ocean circulation models. Journal of Physical Oceanography, 20(1), 150-155.

Griffies, S. M., A. Biastoch, C. Böning, F. Bryan, G. Danabasoglu, E. P. Chassignet, M. H. England, R. Gerdes, H. Haak, R. W. Hallberg, W. Hazeleger, J. Jungclaus, W. G. Large, G. Madec, A. Pirani, B. L. Samuels, M. Scheinert, A. Sen Gupta, C. A. Severijns, H. L. Simmons, A. M. Treguier, M. Winton, S. Yeager and J. Yin, 2009. Coordinated Ocean-ice Reference Experiments (COREs). Ocean Modelling, 26, pp 1-46.

Griffies, S. M., J. Yin, P. J. Durack, P. Goddard, S. C. Bates, E. Behrens, M. Bentsen, D. Bi, A. Biastoch, C. W. Böning, A. Bozec, E. Chassignet, G. Danabasoglu, S. Danilov, C. Domingues, H. Drange, R. Farneti, E. Fernandez, R. J. Greatbatch, D. M. Holland, M. Ilicak, W. G. Large, K. Lorbacher, J. Lu, S. J. Marsland, A. Mishra, A. J. G. Nurser, D. Salas y Mélia, J. B. Palter, B. L. Samuels, J. Schröter, F. U. Schwarzkopf, D. Sidorenko, A. M. Treguier, Y. Tseng, H. Tsujino, P. Uotila, S. Valcke, A. Voldoire, Q. Wang, M. Winton and X. Zhang, 2014. An assessment of 
global and regional sea level for years 1993-2007 in a suite of interannual CORE-II simulations. 602 Ocean Modelling, 78, pp 35-89.

603

604

605

606

607

608

609

610

Hibler, W. D. III, 1979. A dynamic thermodynamic sea ice model. J. Phys.Oceanogr.,9, 815846.

Jakobsen, E., T. Vihma, T. Palo, L. Jakobsen, H. Keernik and J. Jaagas, 2012. Validation of atmospheric reanalyses over the central Arctic Ocean. Geophysical Research Letters, 39, L10820.

Jayne, S. R., and Marotzke, J., 2001. The dynamics of ocean heat transport variability. Reviews of Geophysics, Vol. 39, 385-411.

Kalnay, E., and Coauthors, 1996. The NCEP/NCAR 40-Year Reanalysis Project. Bull. Amer. Meteor. Soc., 77, 437-471.

Kistler, R. and Coauthors, 2001. The NCEP/NCAR 50-year reanalysis: monthly means CDROM and documentation. Bull. Am. Meteorol. Soc., 82(2), 247-267.

Kwok, R., Cunningham, G. F., Wensnahan, M., Rigor, I., Zwally, H. J., and Yi, D., 2009. Thinning and volume loss of the Arctic Ocean sea ice cover: 2003-2008. Journal of Geophysical Research: Oceans (1978-2012), 114(C7).

Large, W., Yeager, S.G., 2004. Diurnal to decadal global forcing for ocean and sea-ice models: The data sets and flux climatologies. Tech. Rep. TN-460+STR, NCAR, 105 pp.

Large, W., Yeager, S.G., 2009. The global climatology of an interannually varying air-sea flux data set, Clim. Dyn., 33, 341-364.

Li, G., Xie, S.P., 2014. Tropical Biases in CMIP5 Multimodel Ensemble: The Excessive Equatorial Pacific Cold Tongue and Double ITCZ Problems. Journal of Climate, 27(4), 17651780 .

Locarnini, R.A., Mishonov, A.V., Antonov, J. I., Boyer, T. P., Garcia, H. E, 2006. World Ocean Atlas 2005, Volume 1: Temperature. S. Levitus, Ed. NOAA Atlas NESDIS 61, U.S. Government Printing Office, Washington, D.C., 182 pp.

Lohmann, K., Latif, M., 2007. Influence of El Niño on the upper-ocean circulation in the tropical Atlantic Ocean. Journal of Climate, 20(19), 5012-5018.

Losch, M., Menemenlis, D., Campin, J. M., Heimbach, P., Hill, C., 2010. On the formulation of sea-ice models. Part 1: Effects of different solver implementations and parameterizations. Ocean Modelling, 33(1), 129-144.

Lu, P., McCreary Jr, J. P., Klinger, B. A., 1998. Meridional circulation cells and the source waters of the Pacific equatorial undercurrent. Journal of Physical Oceanography, 28(1), 62-84. 
Marshall, J., Adcroft, A., Hill, C., Perelman, L., Heisey, C., 1997. A finite volume, incompressible Navier Stokes model for studies of the ocean on parallel computers, Journal of Geophysical Research, 102(C3), 5753 -5766.

McCreary Jr, J. P., Lu, P., 1994. Interaction between the subtropical and equatorial ocean circulations: The subtropical cell. Journal of Physical Oceanography, 24(2), 466-497.

Milliff, R. F., W. G. Large, J. Morzel, G. Danabasoglu, and T. M. Chin, 1999. Ocean general circulation model sensitivity to forcing from scatterometer winds. J. Geophys. Res., 104, 11337 11358.

Naud, C.M. and J. F. Booth, 2014. Evaluation of ERA-Interim and MERRA Cloudiness in the Southern Ocean. Journal of Climate, 27 (5), pp 2109-2124. doi: 10.1175/JCLI-D-13-00432.1

Nicolas, J.P. and D.H. Bromwich, 2011. Precipitation Changes in High Southern Latitudes from Global Reanalyses: A Cautionary Tale. Surveys in Geophys., 32(4-5), 475-494

Onogi, K. and co-authors, 2005. Japanese 25-year re-analysis project - progress and status. Q. J. R. Meteorol. Soc., 131, 3259-3268.

Pavlis, N. K., Holmes, S. A., Kenyon, S. C., Factor, J. K., 2012. The development and evaluation of the Earth Gravitational Model 2008 (EGM2008). Journal of Geophysical Research, 117(B4).

Redi, M. H., 1982. Oceanic isopycnal mixing by coordinate rotation. Journal of Physical Oceanography, 12(10), 1154-1158.

Reynolds, R.W., Smith, T. M., Liu, C., Chelton, D. B., Casey, K. S., Schlax, M. G., 2007. Daily high-resolution-blended analyses for sea surface temperature. Journal of Climate, 20(22), 54735496.

Reznik, G.M., Zeitlin, V. 2009. Resonant excitation of coastal Kelvin waves by inertia-gravity waves. Physics Letters A, 373(11), 1019-1021.

Rienecker, M. M., and Coauthors, 2011. MERRA: NASA's Modern-Era Retrospective Analysis for Research and Applications. J. Climate, 24, 3624-3648.

Rudels, B., Jones, E. P., Anderson, L. G., Kattner, G. On the Intermediate Depth Waters of the Arctic Ocean, in The Polar Oceans and Their Role in Shaping the Global Environment (eds O. M. Johannessen, R. D. Muench and J. E. Overland), American Geophysical Union, Washington, D. C.

Rudels, B., Anderson, L.G., Jones, E. P., 1996. Formation and evolution of the surface mixed layer and halocline of the Arctic Ocean, J. Geophys. Res., 101(C4), 8807-8821

Saha, S, and Coauthors, 2010. The NCEP Climate Forecast System Reanalysis. Bull. Amer. Meteor. Soc., 91, 1015-1057. 
Saito,M, Ito,A, and Maksyutov,S., 2011. Evaluation of Biases in JRA-25/JCDAS Precipitation and Their Impact on the Global Terrestrial Carbon Balance. J. Climate, 24, 4109-4125.

Smith, W. H. F., Sandwell, D. T., 1997. Global Seafloor Topography from Satellite Altimetry and Ship Depth Soundings, Science 277: 1956-1962.

Stammer, D., Wunsch C., Giering, R., Eckert, C., Heimbach, P., Marotzke, J., Adcroft, A., Hill, observations and a general circulation model, Journal of Geophysical Research: Oceans 107, 1-1.

Sun, B., L. Yu, and R. A. Weller, 2003. Comparisons of surface meteorology and turbulent heat fluxes over the Atlantic: NWP model analyses versus moored buoy observations. $J$. Climate, 16, 679-695.

Toggweiler, J.R., Samuels, B., 1993. Is the magnitude of the deep outflow from the Atlantic Ocean actually governed by Southern Hemisphere winds?. In The Global Carbon Cycle (pp. 303-331). Springer Berlin Heidelberg.

Tomczak, M., Godfrey, S.J.S., 1994. Regional Oceanography: An Introduction. Pergamon. 422pp.

Trenberth, K. E. and J. T. Fasullo, 2010. Simulation of Present-Day and Twenty-First-Century Energy Budgets of the Southern Oceans. Journal of Climate, 23 (2), pp 440-454.

Uppala, S. M., and Coauthors, 2005. The ERA40 reanalysis. Quart. J. Roy. Meteor. Soc., 131, 2961-3012.

Wang, W, and M.J. McPhaden, 2001. Surface Layer Temperature Balance in the Equatorial Pacific during the 1997-98 El Niño and 1998-99 La Niña. J. Climate, 14, 3393-3407.

Wunsch, C., Heimbach, P., 2006. Estimated decadal changes in the North Atlantic meridional overturning circulation and heat flux 1993-2004. Journal of Physical Oceanography, 36(11), 2012-2024.

Wunsch, C., Heimbach, P., 2007. Practical global ocean state estimation. Physica D, 230, 197208.

Wunsch, C., Heimbach, P., Ponte, R.M., Fukumori, I., 2009. The global general circulation of the ocean estimated by the ECCO-consortium. Oceanography, 22, 88-103.

Xue, Y., B. Huang, Z.-Z. Hu, A. Kumar, C. Wen, D. Behringer and S. Nadiga, 2011. An assessment of oceanic variability in the NCEP climate forecast system reanalysis. Climate Dynamics, 37 (11-12), pp 2511-2539.

Yu, L., Weller, R.A., 2007. Objectively analyzed air-sea heat fluxes for the global ice-free oceans (1981-2005). 
728 Zhang, Y.C., Rossow, W.B., Lacis, A.A., Oinas, V., Mishchenko, M.I., 2004. Calculation of 729 radiative fluxes from the surface to top of atmosphere based on ISCCP and other global data sets: 730 refinements of the radiative transfer model and the input data. J. Geophys. Res. 109, D19105.

731

732 Zhang, J., Hibler III, W.D., 1997. On an efficient numerical method for modeling sea ice 733 dynamics, J. Geophys. Res., 102(C4), 8691-8702. Zhang, J., Hibler III, W. D., Steele, M., Rothrock, D. A., 1998. Arctic ice-ocean modeling with 736

738 Zika, J.D., England, M.H., Sijp, W.P., 2012. The ocean circulation in thermohaline coordinates. 739 J. Phys. Oceanogr., 42(5), 708-724. 


\section{TABLES}

\begin{tabular}{|l|l|l|l|}
\hline Reanalysis & Resolution & Range & Assimilation Scheme \\
\hline MERRA & $0.5^{\circ} \times 0.667^{\circ} \times 72$ levels & 1979 -Present & GEOS -DAS \\
\hline ERA & $0.75^{\circ} \times 0.75^{\circ} \times 60$ levels & 1979 -Present & 4DVAR \\
\hline JRA & $1.125^{\circ} \times 1.125^{\circ} \times 40$ levels & $1979-$ Present & 3DVAR \\
\hline CFSR & $0.5^{\circ} \times 0.5^{\circ} \times 64$ levels & $1979-$ Present & 3DVAR \\
\hline
\end{tabular}

Table 1. Information about the reanalysis products used in this study.

\begin{tabular}{|l|l|l|l|l|}
\hline & ERA & JRA & CFSR & MERRA \\
\hline RMSD SST $\left({ }^{\circ} \mathrm{C}\right)$ & 0.48 & 0.47 & 0.46 & 0.47 \\
\hline RMSD SLA $(\mathrm{m})$ & 0.083 & 0.087 & 0.079 & 0.080 \\
\hline
\end{tabular}

Table 2: Global root-mean-square differences between model derived SST and SLA against Reynolds SST and altimeter derived SLA. 


\section{FIGURE CAPTIONS}

Figure 1: Top: Mean (left panel) and standard deviation (right panel) of zonally averaged zonal wind stress for the 4 reanalysis models. Bottom: as in top panels but for zonally averaged global precipitation flux.

Figure 2: Values of $M_{m}$ (root-mean-square time-mean model-model difference), $M_{v}$ (standard deviation of model-model difference), $\mathrm{D}_{\mathrm{m}}$ (time-mean model-observation difference), $\mathrm{D}_{\mathrm{v}}$ (standard deviation of model-observation difference), and respective ratios $M_{m} / D_{m}$ and $M_{v} / D_{v}$ (dimensionless) in sea-surface temperature (SST) $\left[{ }^{\circ} \mathrm{C}\right]$. Reference SST data is from Reynolds et al. (2007). Latitudinal extent from $90^{\circ} \mathrm{S}$ to $90^{\circ} \mathrm{N}$.

Figure 3: Values of $M_{m}, M_{v}, D_{m}, D_{v}$ and respective ratios in sea-ice fraction estimated in the Arctic Ocean. Reference data is NSIDC sea-ice concentrations. Latitudinal extent from $60^{\circ} \mathrm{N}$ to $90^{\circ} \mathrm{N}$. Main Arctic seas are denoted as follows: BF-Beaufort Sea, CK-Chukchi Sea, ES-East Siberian Sea, LP-Laptev Sea, KA-Kara Sea, BA-Barents Sea, NR-Norwegian Sea, GRGreenland Sea. Ice-free regions are masked in the ratios.

Figure 4: Same as Fig. 3 for the Southern Ocean. Latitudinal extent from $60^{\circ} \mathrm{N}$ to $90^{\circ} \mathrm{N}$. Main Antarctic sectors are denoted as follows: IS-Indian Sector, PS-Pacific Sector, RS-Ross Sea Sector, BAS-Bellingshausen and Amundsen Sea Sector, WS-Weddell Sea Sector. Ice-free regions are masked in the ratios.

Figure 5: As in Fig. 3 but for values of $M_{m}, M_{v}, D_{m}$ and $D_{v}$ and their ratios in fall sea-ice thickness $(\mathrm{m})$. Reference data is ICESat-derived sea-ice thickness.

Figure 6: Values of $M_{m}, D_{m}, M_{v}$ and $D_{v}$ and respective ratio in sea-level anomaly (m). Reference data for time-mean errors is mean dynamic topography derived from the Mean Sea Surface constructed by Andersen and Knudsen (2009) and the geoid constructed by Pavlis et al. (2012), whereas AVISO sea-level anomalies are used as reference for time-variable errors.

Figure 7: Values of $M_{m}, M_{v}$ in vertically integrated streamfunction (Sv).

Figure 8: $\log _{10}$ values of $\mathrm{M}_{\mathrm{m}}$ and $\mathrm{M}_{\mathrm{v}}$ for zonally averaged overturning circulation (Sv) including bolus terms for Pacific+Indian basin (PAC+IND), Atlantic Basin (ATL) and Global (GLO).

Figure 9: Estimates of $M_{m}$ (upper panels) and $M_{v}$ (lower panels) for zonally averaged meridional heat transport (left column), freshwater transport, and surface heat and freshwater fluxes (right column), for the 4 reanalysis models.

Figure 10: $\log _{10}$ values of $\mathrm{M}_{\mathrm{m}}$ and $\mathrm{M}_{\mathrm{v}}$ and their ratio in a temperature section $\left[160^{\circ} \mathrm{W}\right.$, $\left.90^{\circ} \mathrm{S}: 90^{\circ} \mathrm{N}\right]$ across the Pacific. The surface landmass between $50-80^{\circ} \mathrm{N}$ is the Alaskan mainland. Reference data is from OCCA (Forget. 2010). 
Figure 11: Same as Fig 10 for salinity.

Figure 12: The first two modes and principal components, along with the variances explained, of SST $\left[{ }^{\circ} \mathrm{C}\right]$ differences between ERA and JRA reanalysis from 2000 to 2009.

Figure 13: The first two modes and principal components, along with the variances explained, of sea-level [m] differences between ERA and JRA reanalysis from 2000 to 2009. 

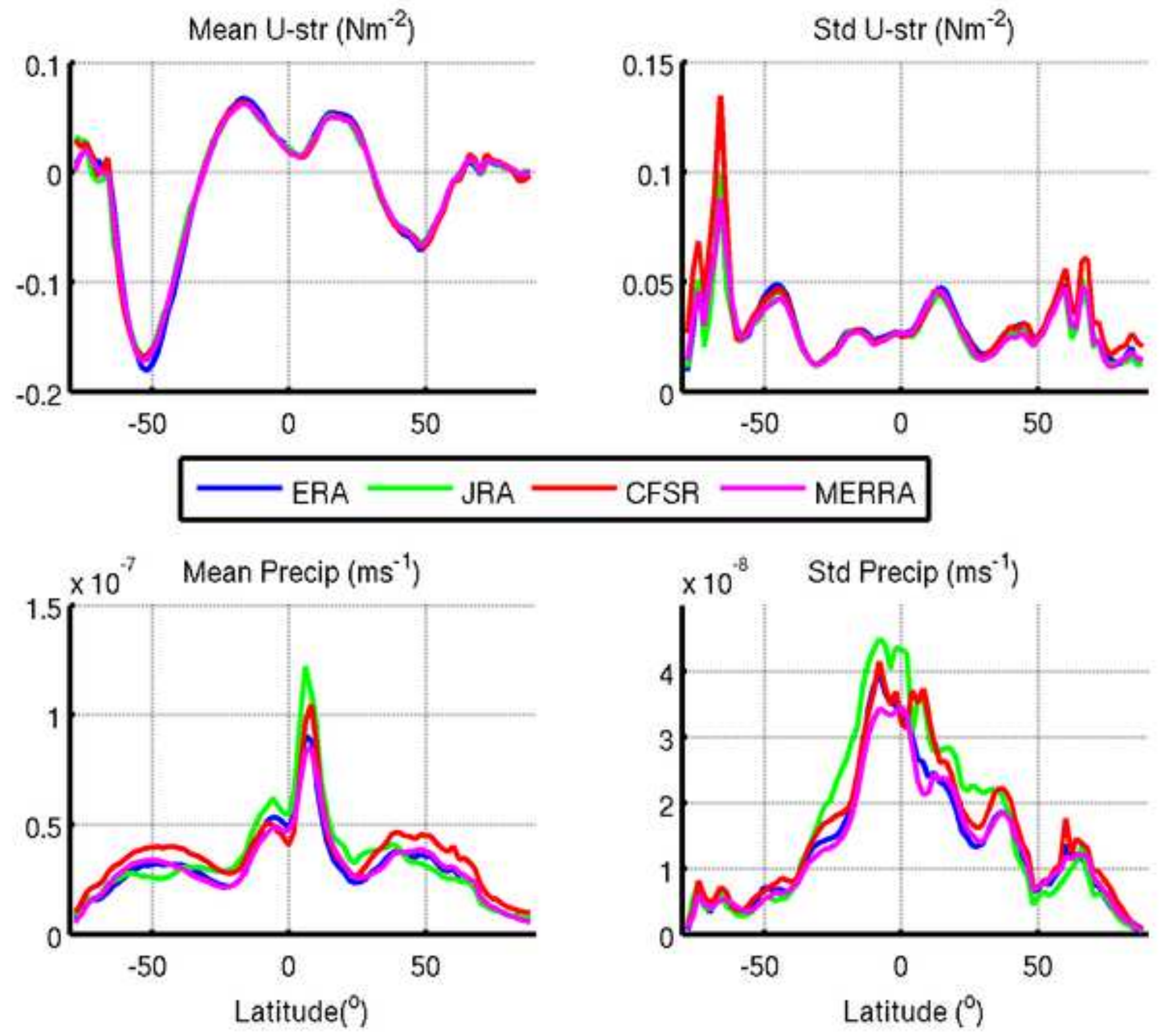

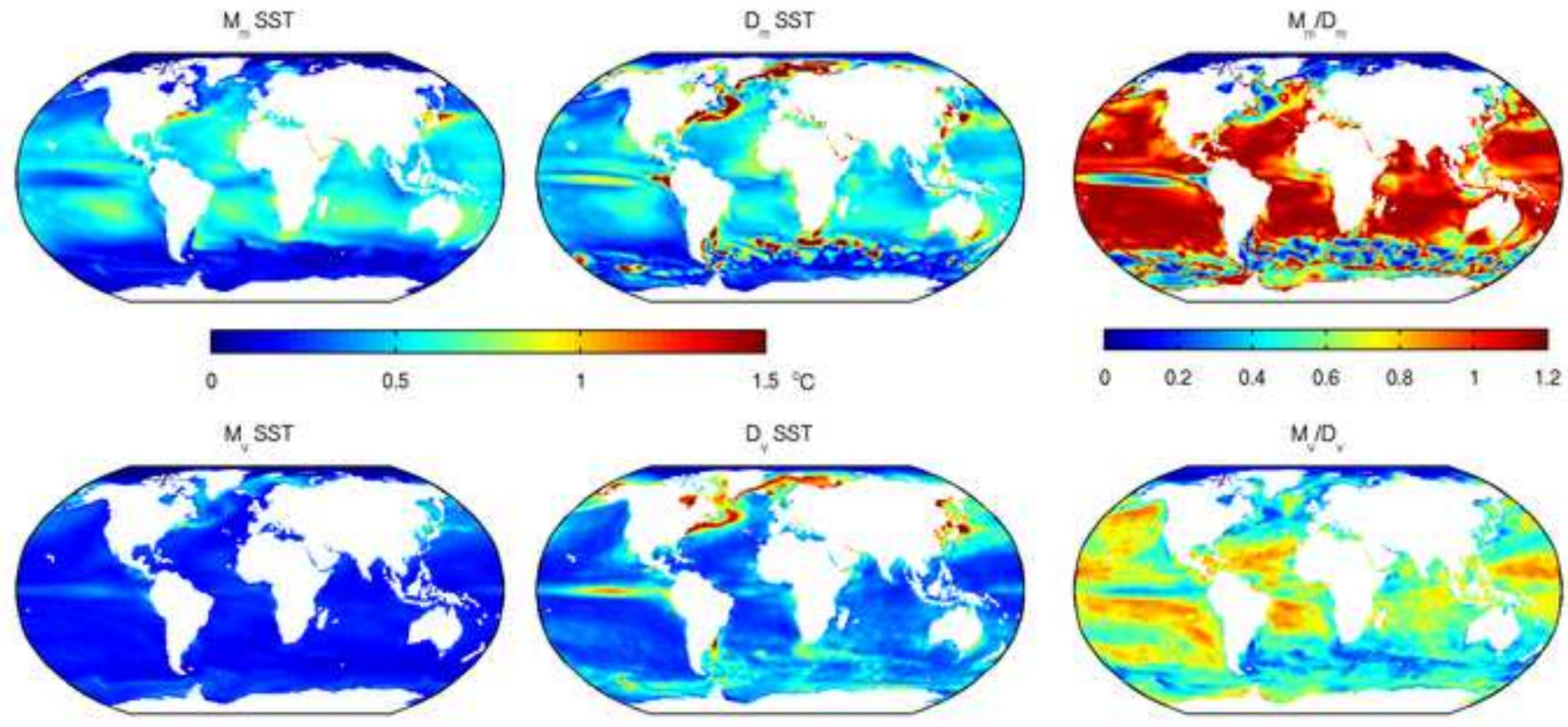

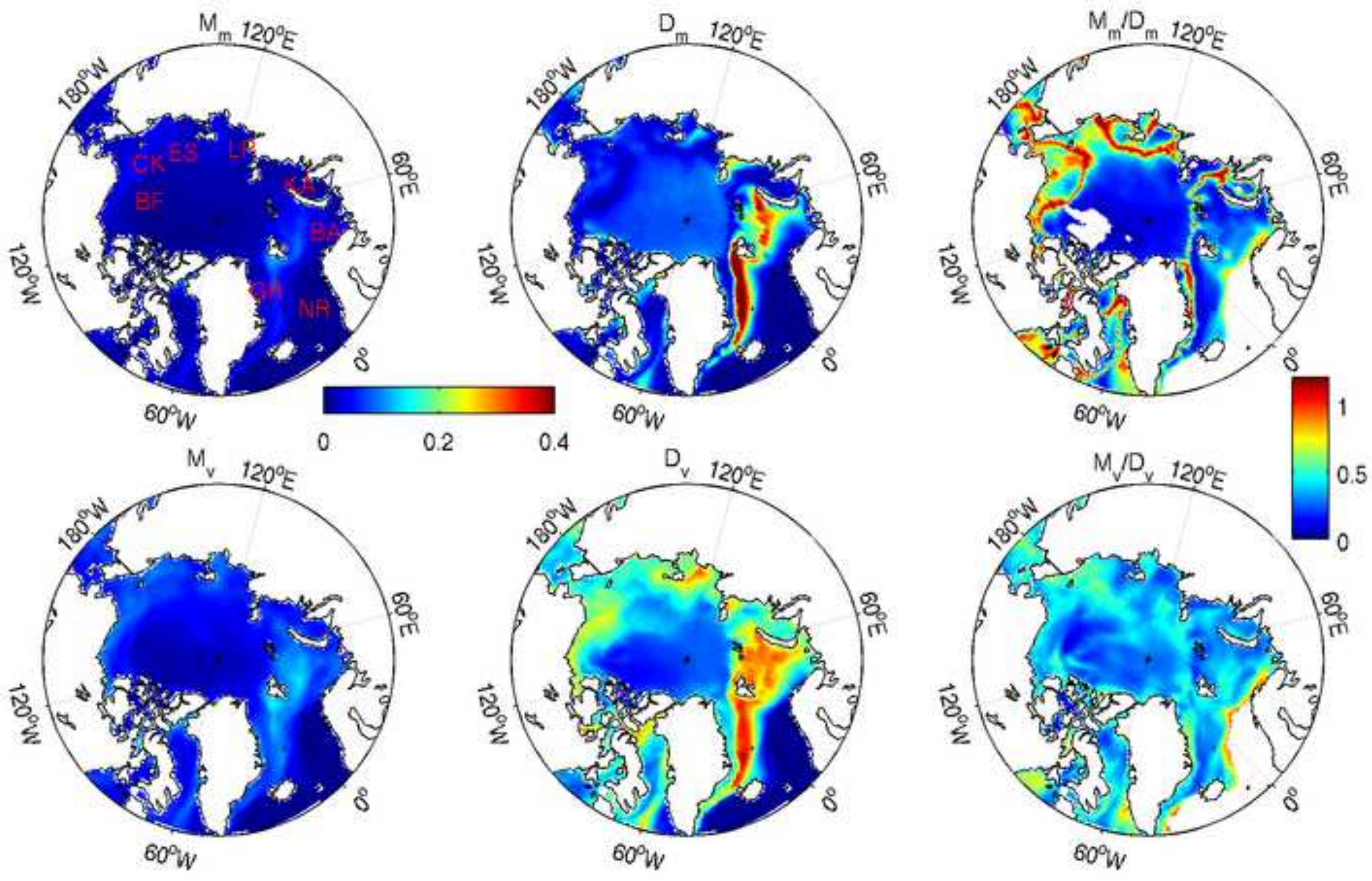

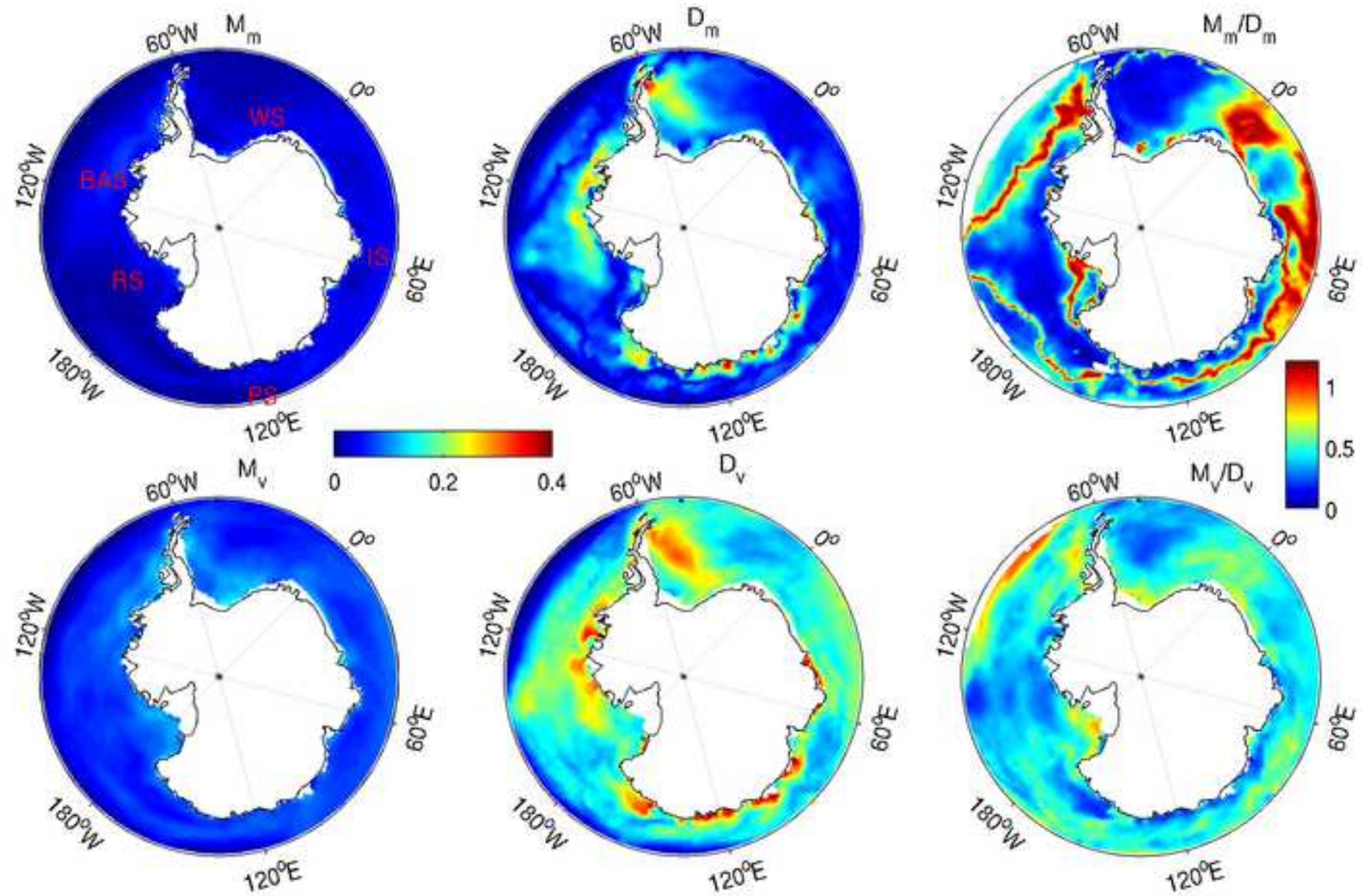

$120^{\circ} \mathrm{E}$ 

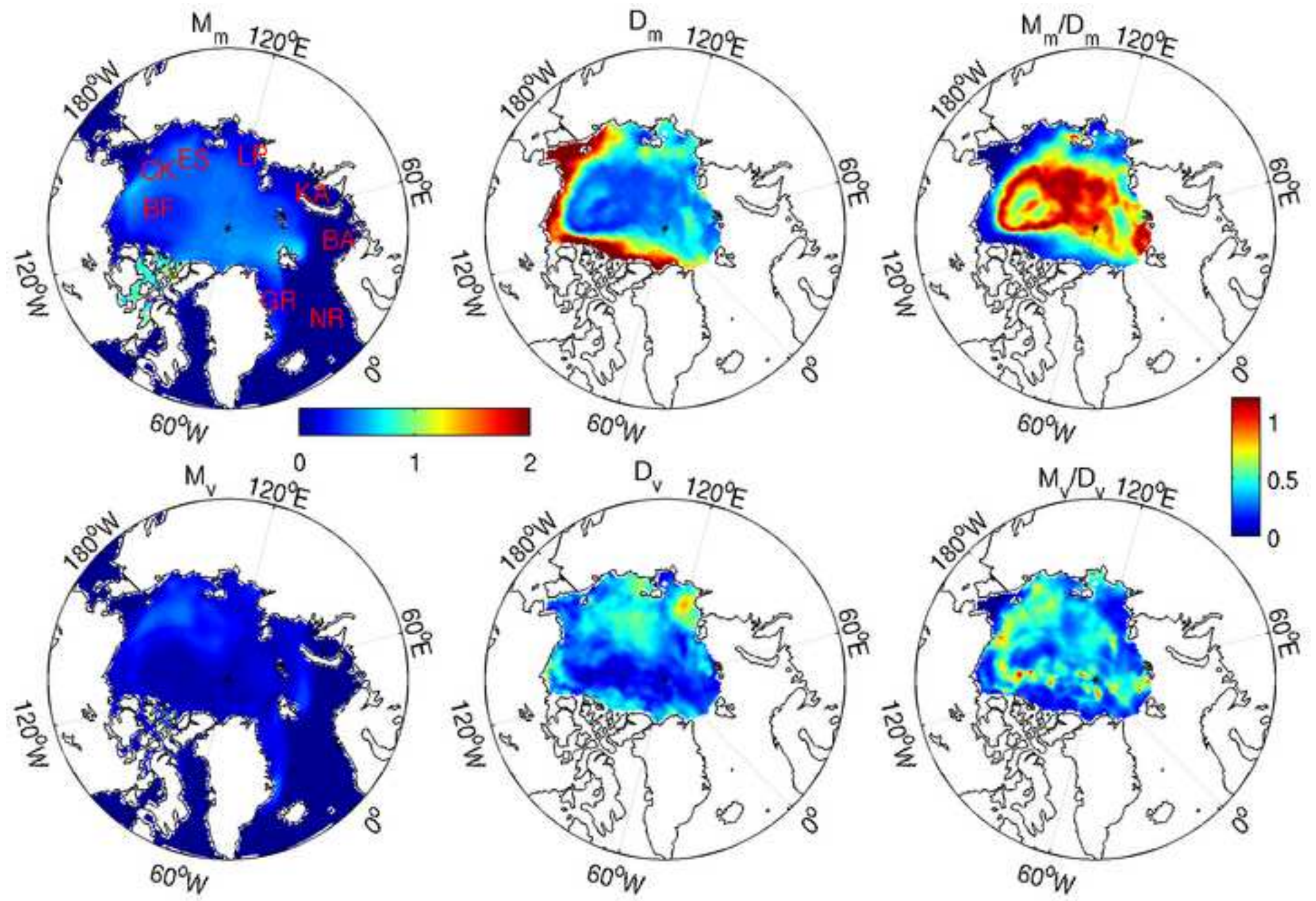

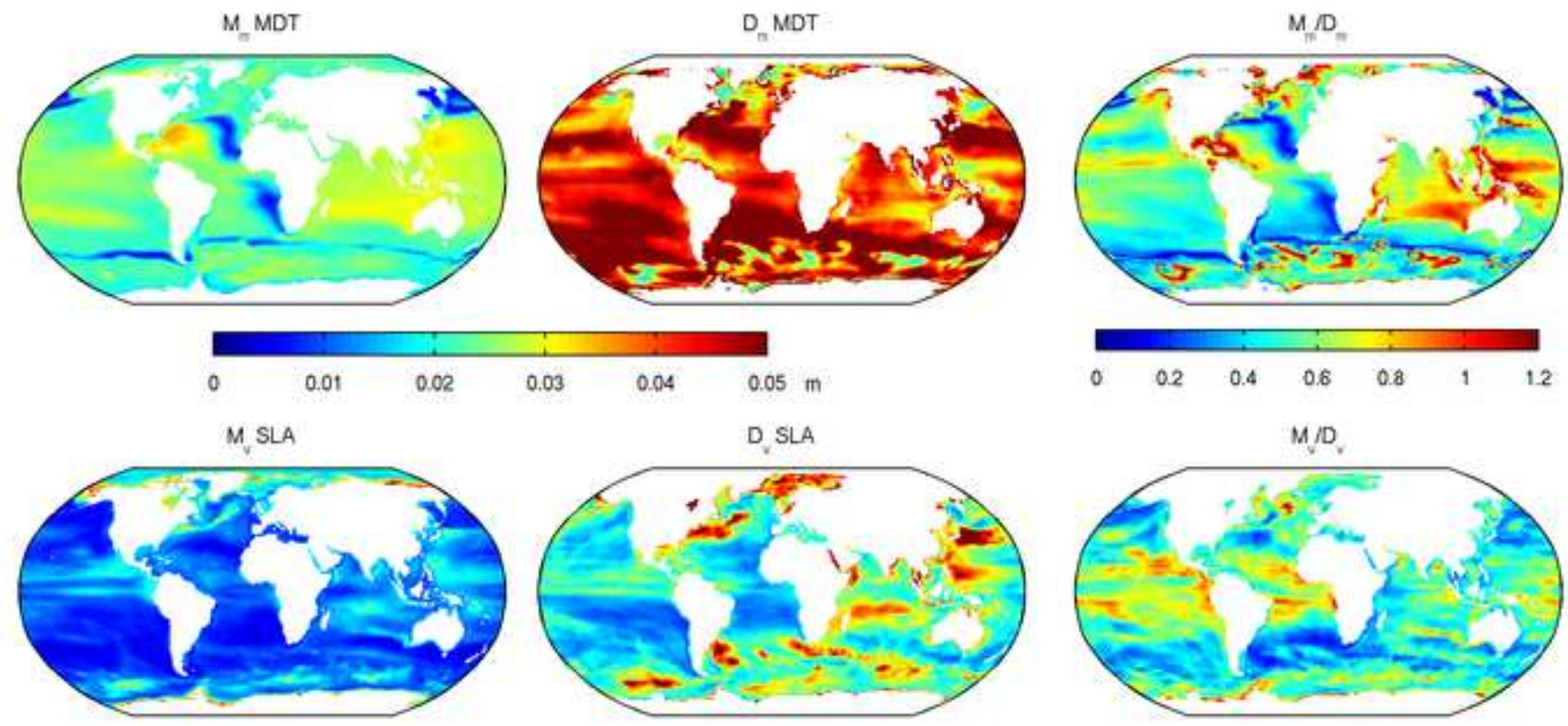


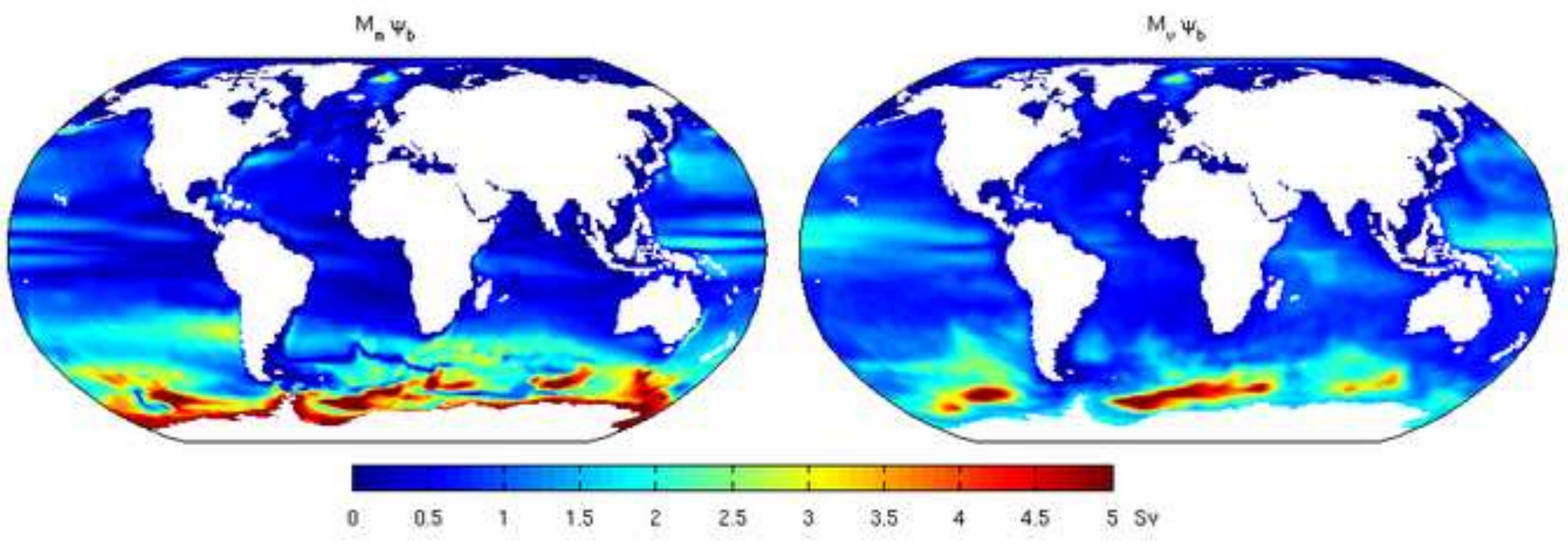



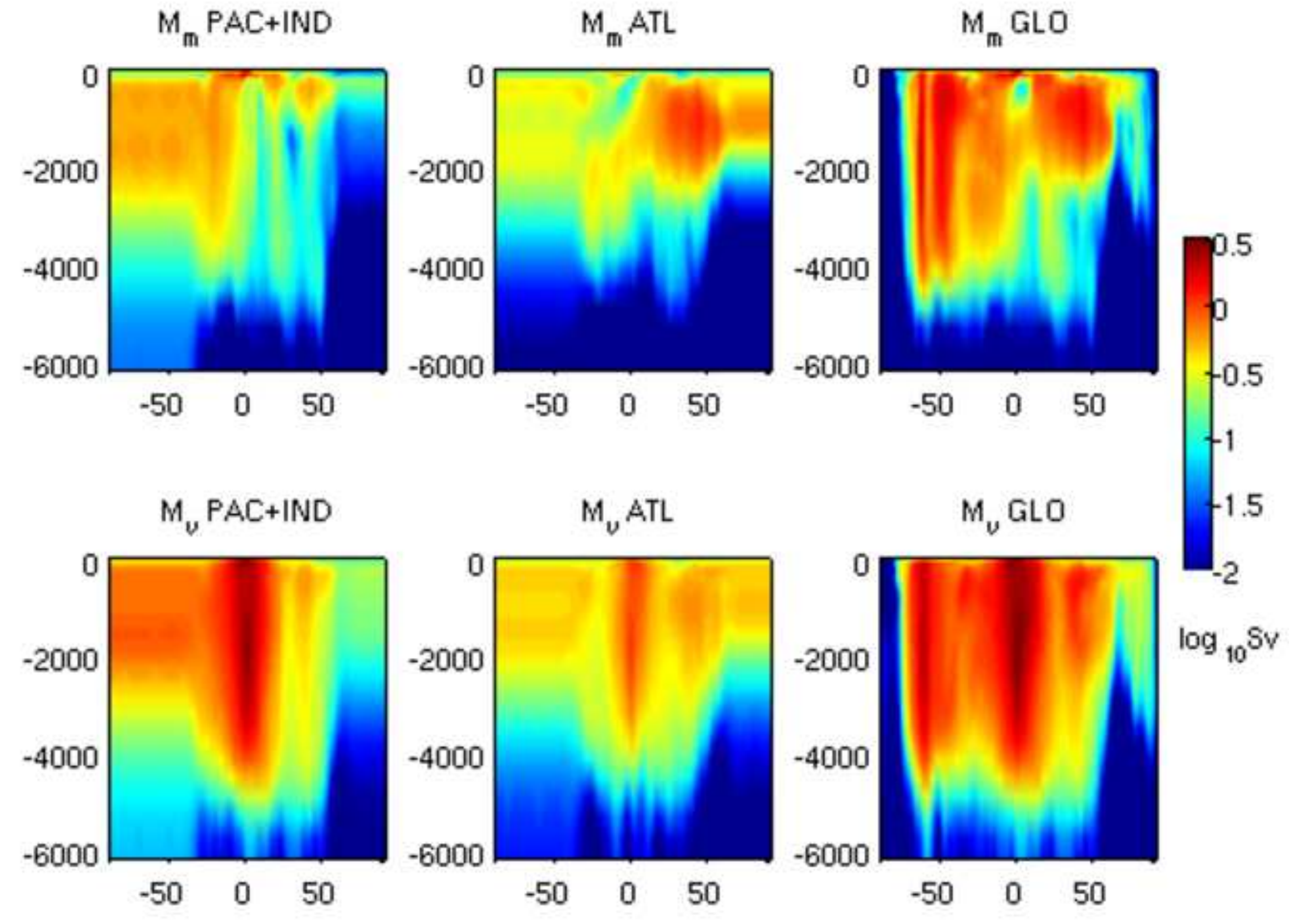


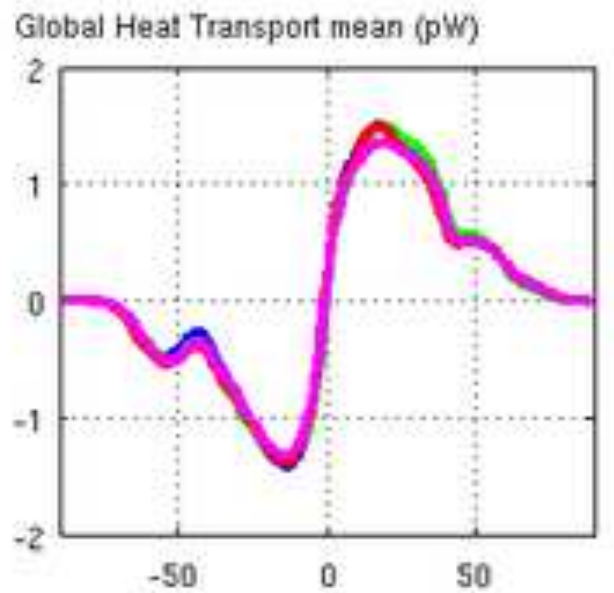

Global Heat Transport std ( $\mathrm{pw}$ )

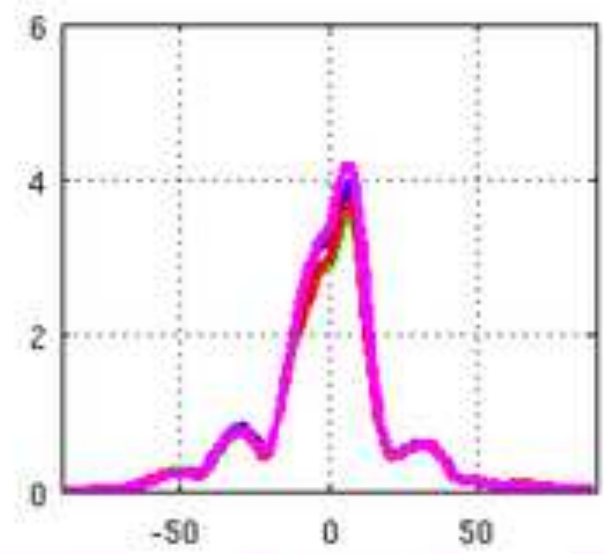

ERA

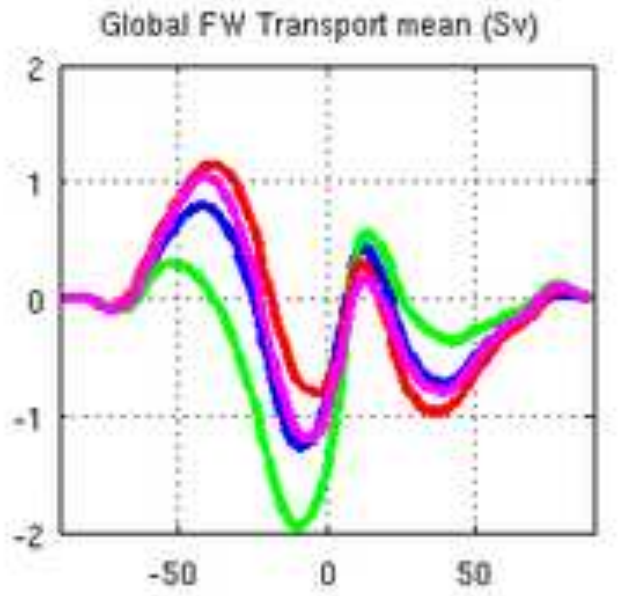

Global FW Transport std (SV)

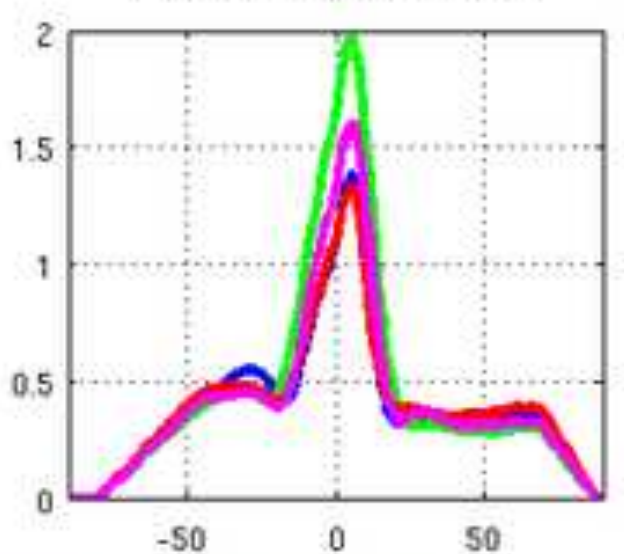

MERRA

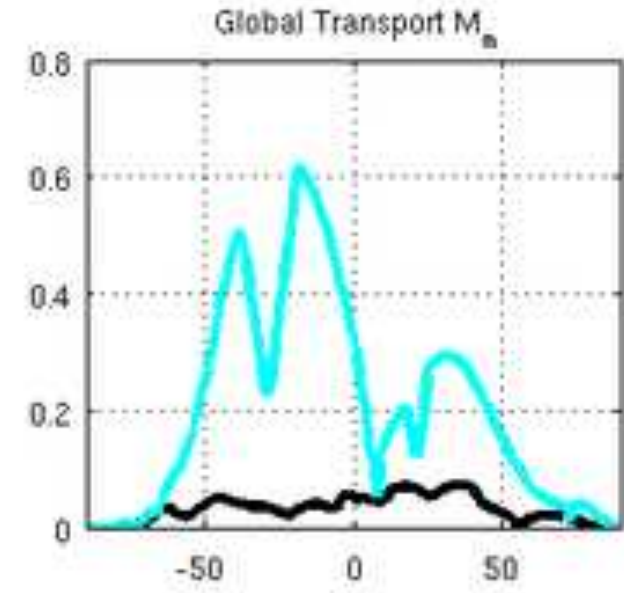

Global Transport $M_{v}$

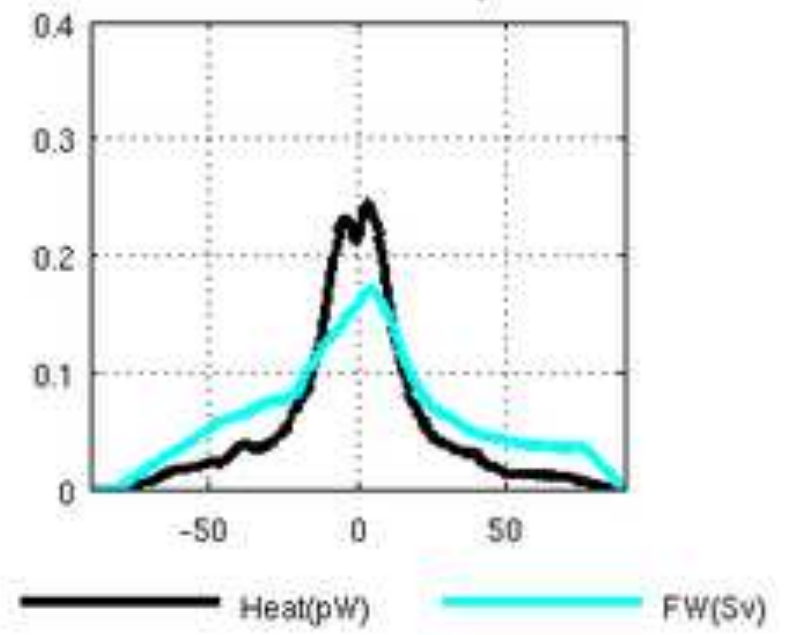


$M_{\mathrm{s}}$ Temp
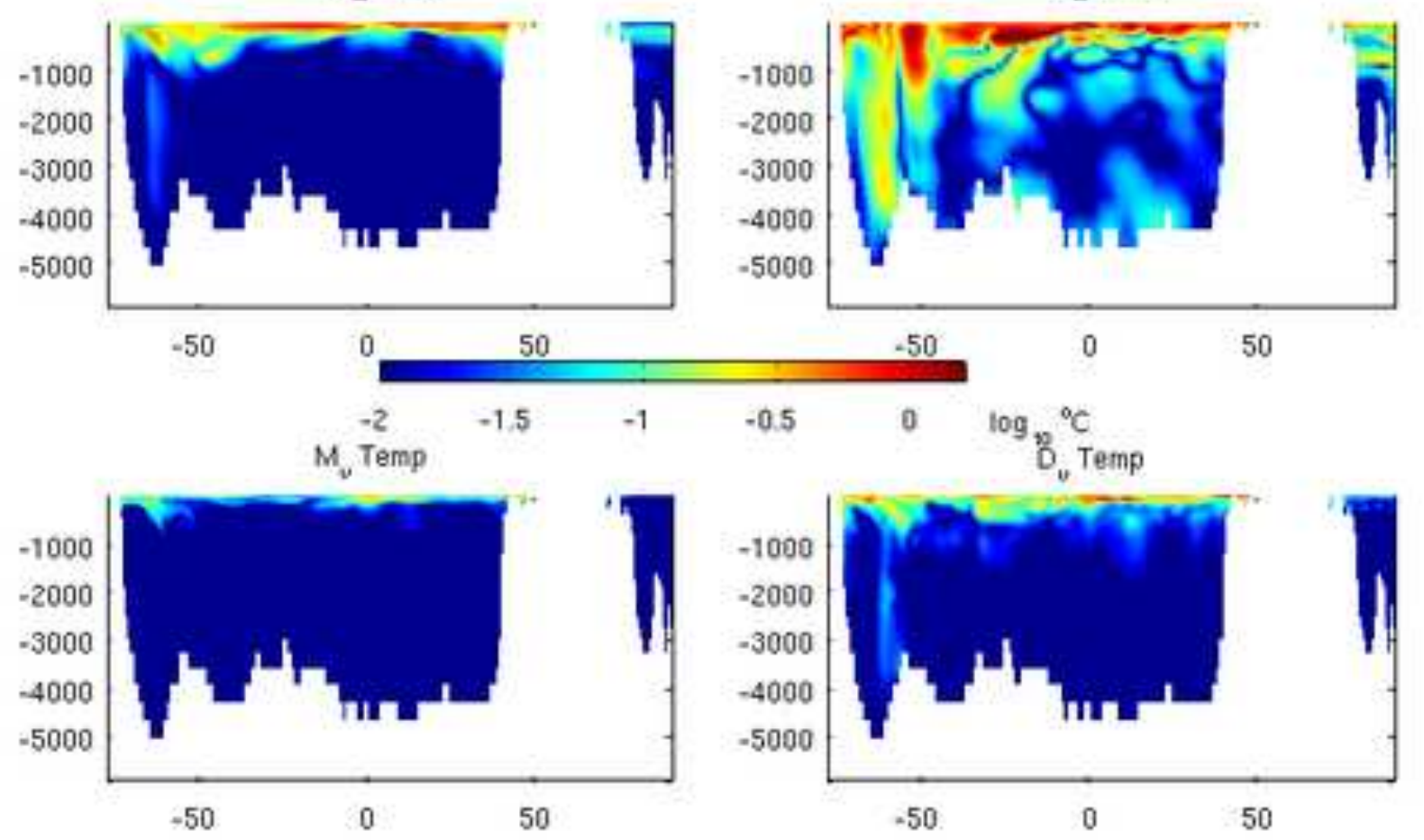

D. Temp

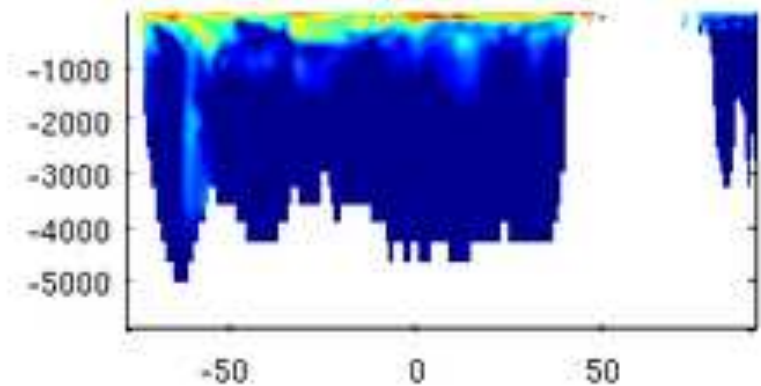

$\mathrm{M}_{\mathrm{a}} \mathrm{D}_{\mathrm{s}}$

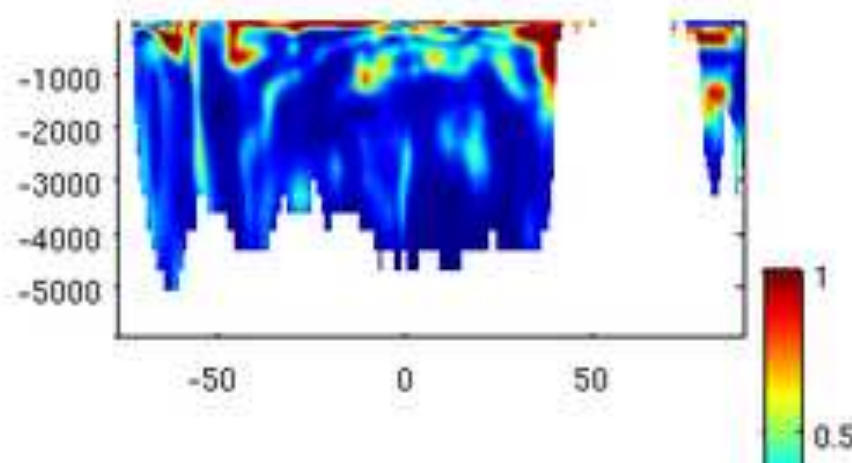

$M_{v} / D_{v}$

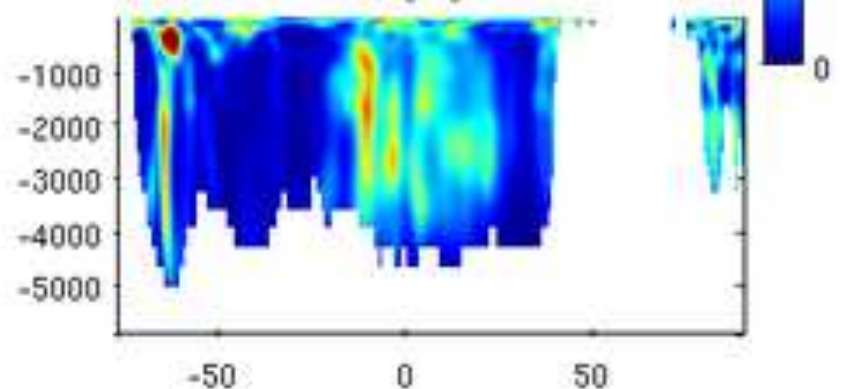



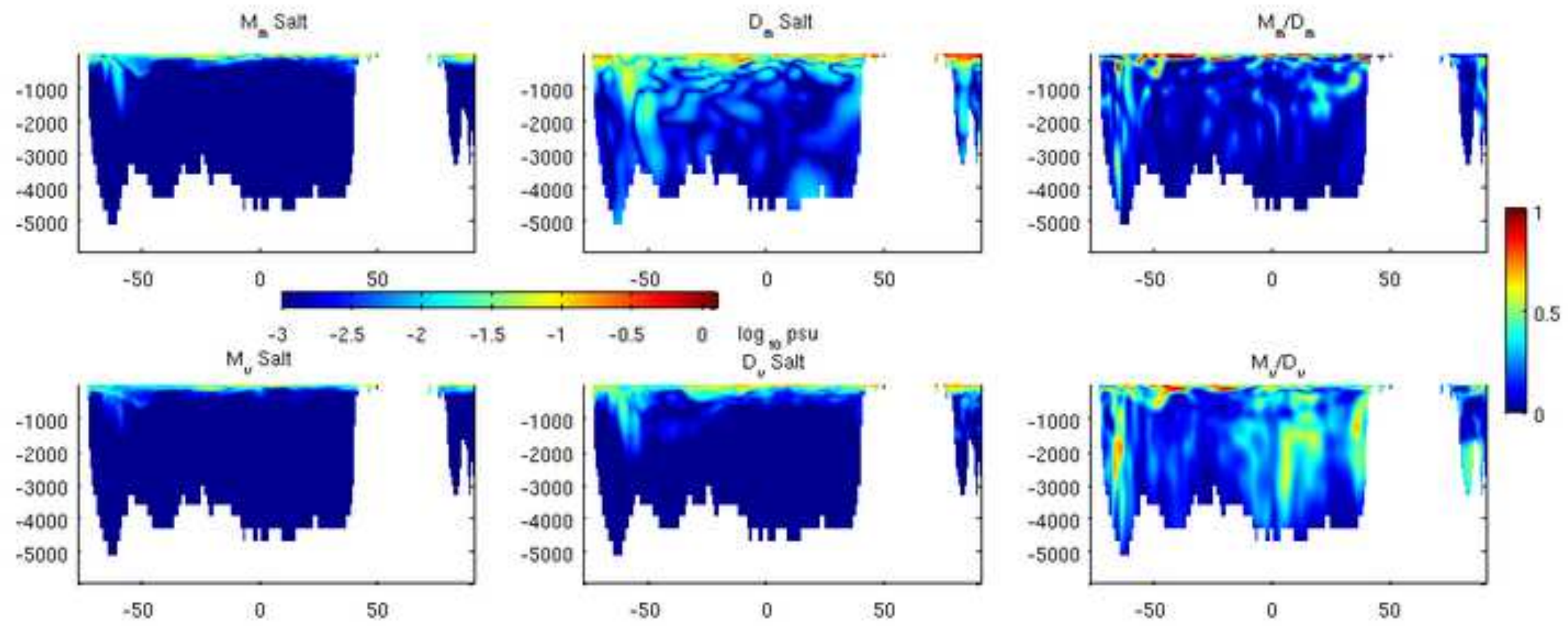

50 

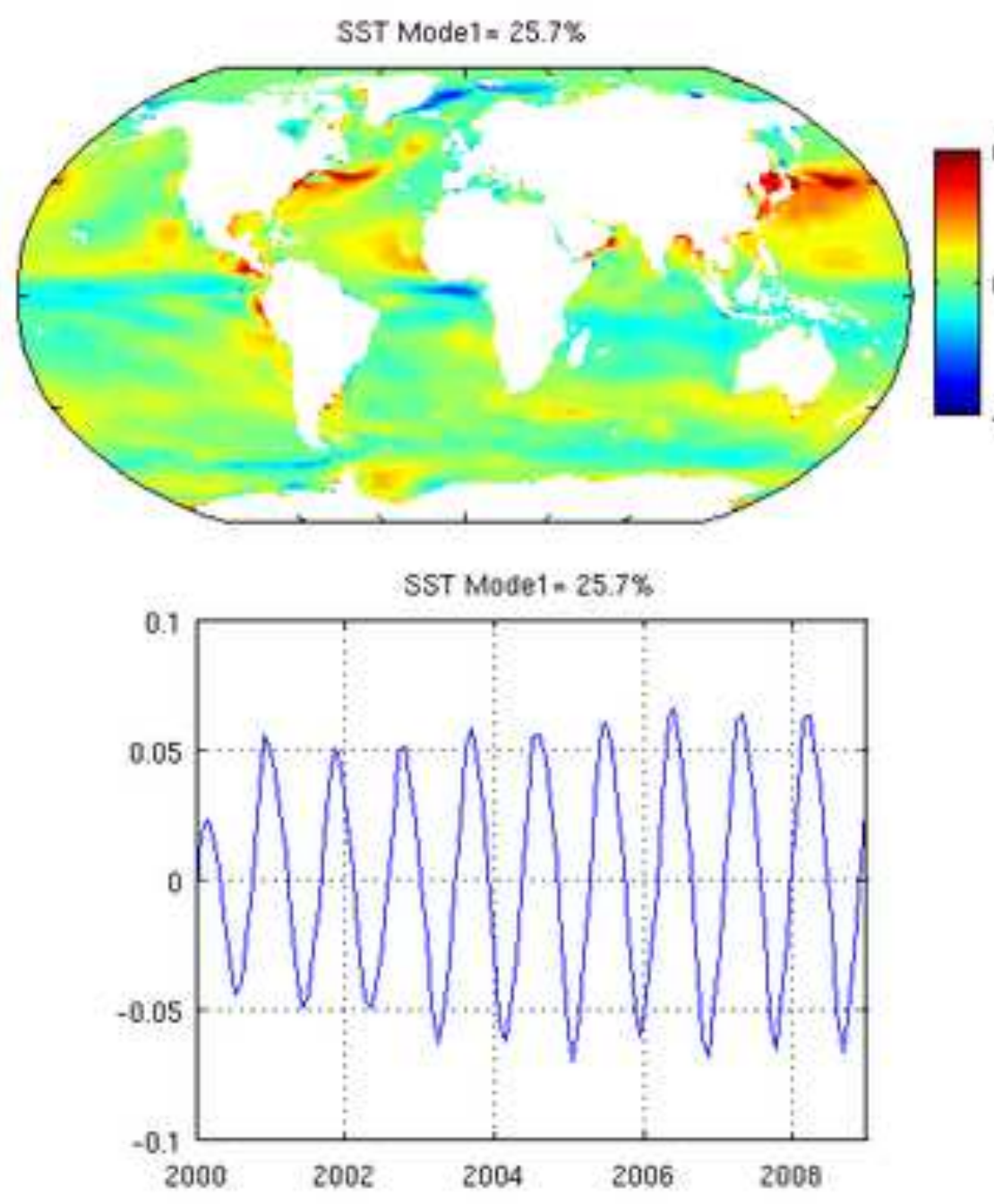

SST Mode2 $=9.6 \%$

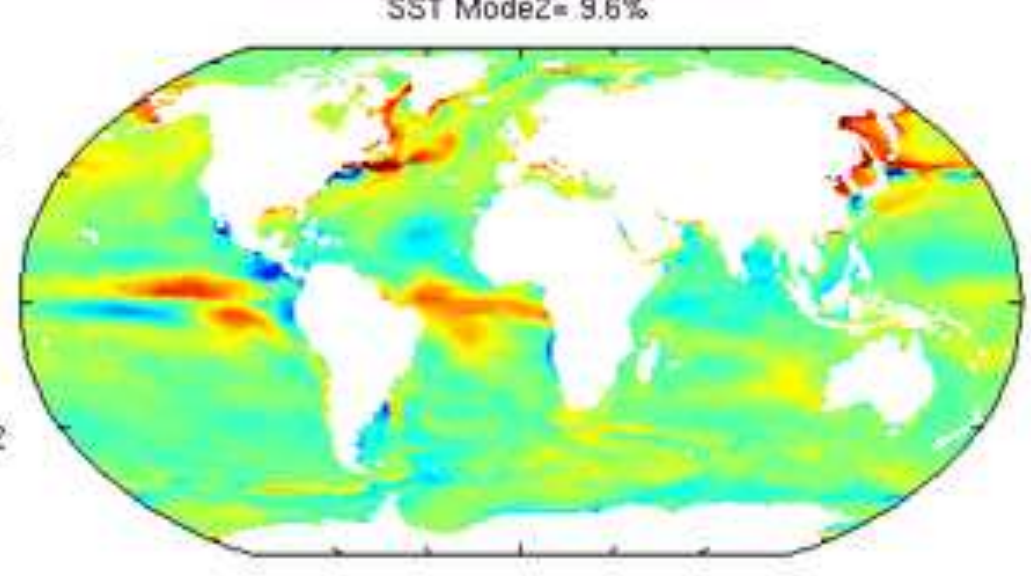

SST Mode $2-9.6 \%$

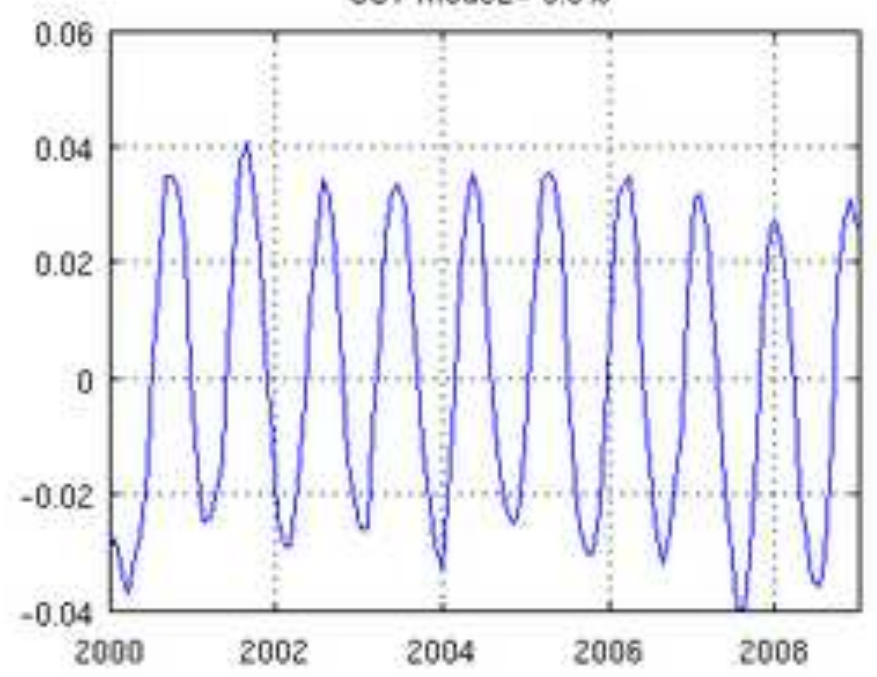


SLA Mode1 $=21 \%$
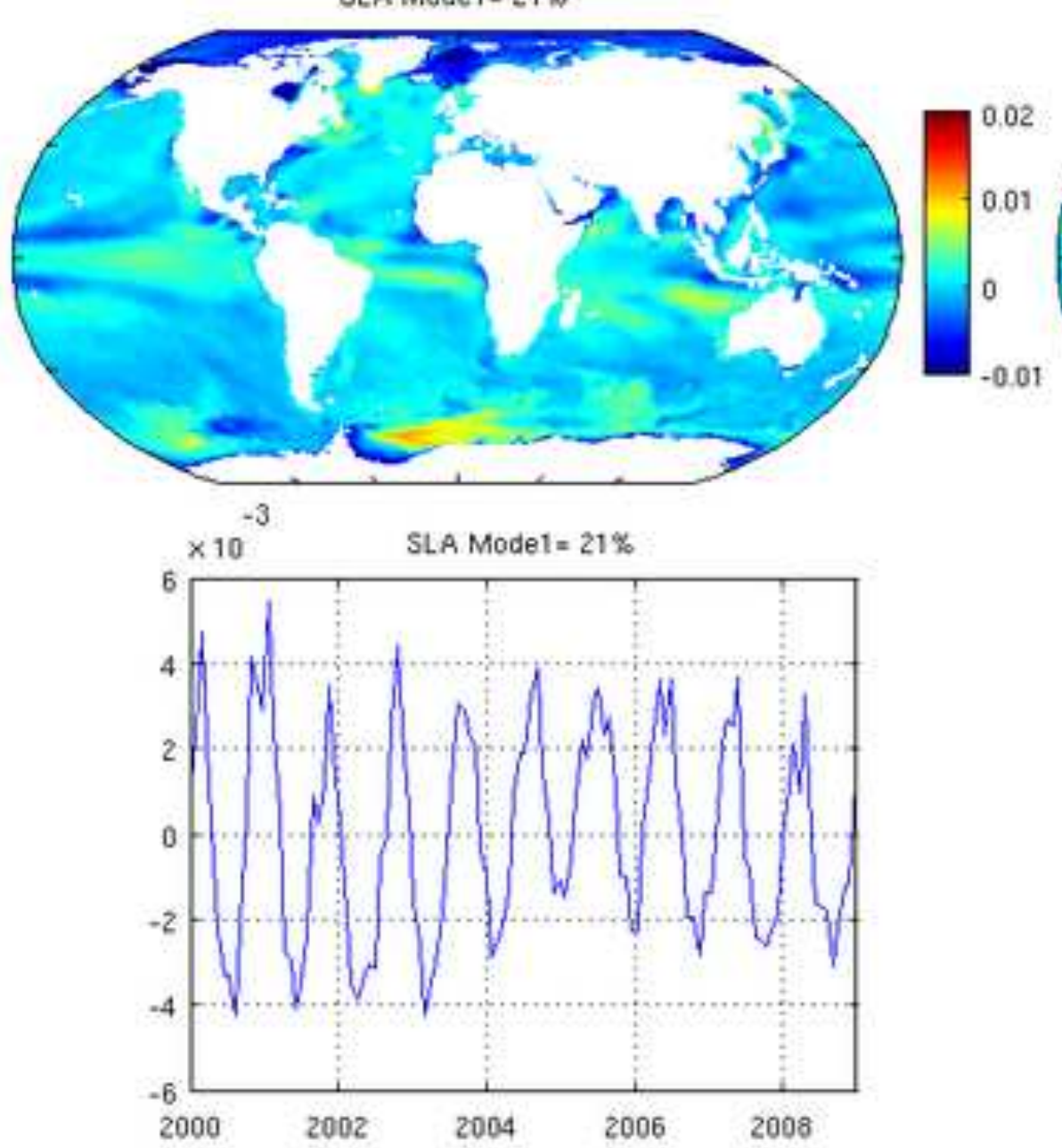

SLA Mode2 = $12.5 \%$
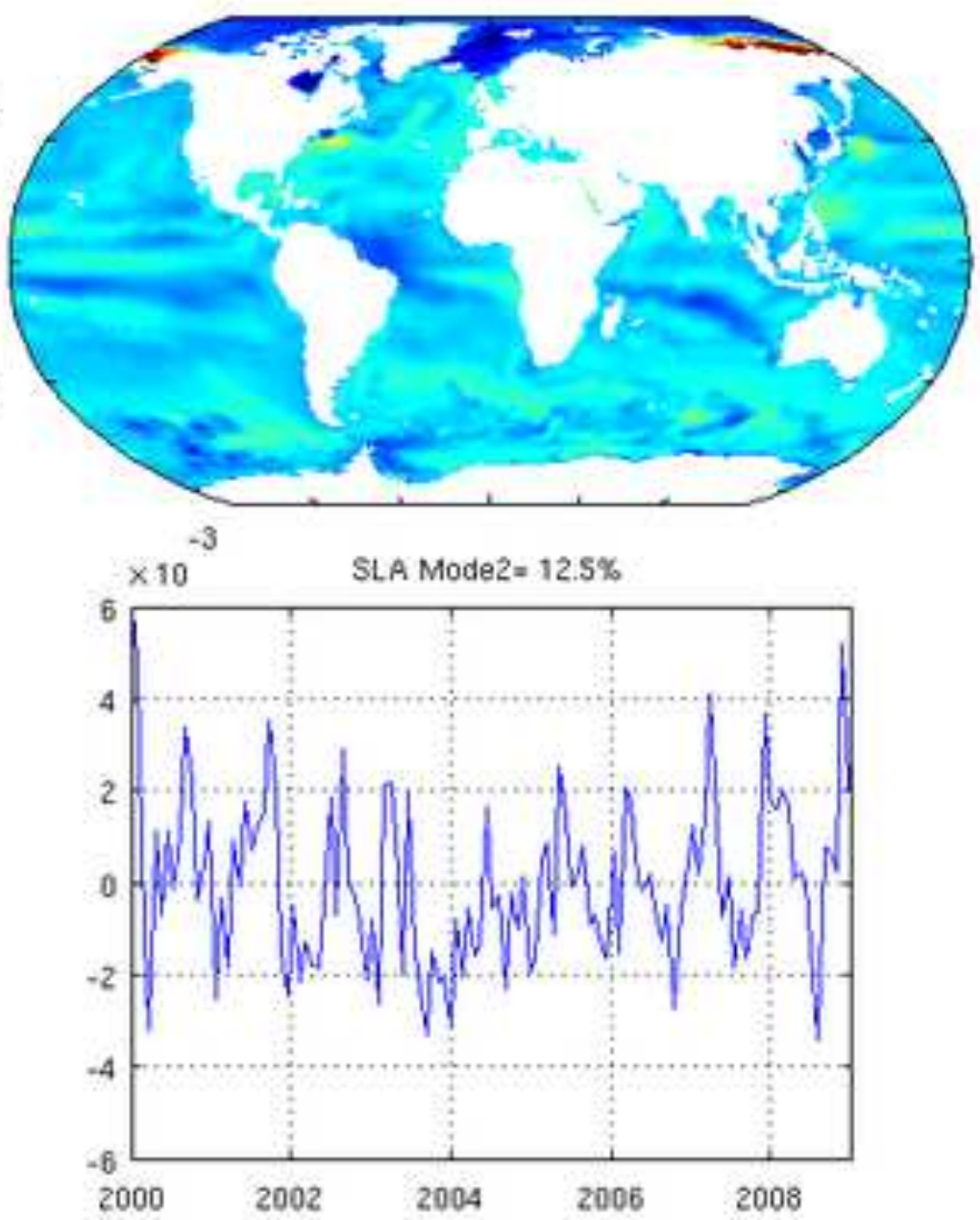